PII S0016-7037(99)00425-1

\title{
Trace element partitioning between coexisting biotite and muscovite from metamorphic rocks, Western Labrador: Structural, compositional and thermal controls
}

\author{
PANSEOK YANG and TOBy Rivers* \\ Department of Earth Sciences, Memorial University of Newfoundland, St. John's, NF, Canada A1B 3X5
}

(Received June 28, 1999; accepted in revised form November 18, 1999)

\begin{abstract}
Coexisting biotite and muscovite in ten metapelitic and quartzofeldspathic rocks from western Labrador have been analyzed by electron microprobe for major and minor elements and by a laser ablation microprobe coupled to ICP-MS (LAM-ICP-MS) for selected trace elements- $\mathrm{Li}, \mathrm{Sc}, \mathrm{V}, \mathrm{Cr}, \mathrm{Mn}, \mathrm{Co}, \mathrm{Ni}, \mathrm{Cu}$, $\mathrm{Zn}, \mathrm{Rb}, \mathrm{Sr}, \mathrm{Y}, \mathrm{Zr}, \mathrm{Nb}, \mathrm{Cs}$, Ba, REE, Hf and Ta. The samples have experienced a single prograde Grenvillian metamorphism ranging from 490 to $680^{\circ} \mathrm{C}$ and from 7 to 12 kbar. The trace element compositions of coexisting micas in the metamorphic rocks are used to assess the effects of crystal structure, major element composition and temperature on the partitioning of each element between biotite and muscovite.

Overall, trace element distributions are systematic across the range of metamorphic grade and bulk composition, suggesting that chemical equilibrium was approached. Most distribution coefficients (biotite/ muscovite) show good agreement with published data. However, distribution coefficients for Co and $\mathrm{Sr}$ are significantly different from previous determinations, probably because of contamination associated with older data obtained by bulk analysis techniques. The sequence of distribution coefficients is governed mainly by the ionic radii and charges of substituting cations compared to the optimum ionic radius of each crystallographic site in the micas. In particular, distribution coefficients exhibit the sequence $\mathrm{Cr}^{3+}(0.615 \AA)>\mathrm{V}^{3+}(0.64 \AA)>$ $\mathrm{Sc}^{3+}(0.745 \AA)$ in VI-sites, and $\mathrm{Ba}^{2+}(1.61 \AA)>\mathrm{Sr}^{2+}(1.44 \AA)$ and $\mathrm{Cs}^{+}(1.88 \AA)>\mathrm{K}^{+}(1.64 \AA)>\mathrm{Rb}^{+}$ $(1.72 \AA)>\mathrm{Na}^{+}(1.39 \AA)$ in XII-sites. The distributions of Li, Sc, Sr and Ba appear to be thermally sensitive but are also controlled by major element compositions of micas. $\mathrm{V}$ and $\mathrm{Zr}$ partitioning is dependent on $\mathrm{T}$ and may be used to cross-check thermometry calculations where the latter suffer from retrograde re-equilibration and/or high concentrations of $\mathrm{Fe}^{3+}$. The ranges and dependence of distribution coefficients on major element compositions provide important constraints on the values that can be used in geochemical modeling. Copyright $($ ) 2000 Elsevier Science Ltd
\end{abstract}

\section{INTRODUCTION}

Major element partitioning between coexisting phases is an important aspect of the characterization of phase equilibrium relationships as a function of pressure $(\mathrm{P})$, temperature $(\mathrm{T})$ and compositional variables $(\mathrm{X})$ and is the basis for classical geothermobarometry (Kretz, 1961). In principle, the concept should also extend to trace element partitioning which should therefore also be useful to estimate P-T conditions during metamorphism (e.g., Heinrich et al., 1997; Bea et al., 1997). In addition to thermobarometry, studies of the partitioning of trace elements among coexisting metamorphic minerals can provide valuable information about equilibrium and petrogenesis (e.g., Haack et al., 1984; Dahl et al., 1993; Hickmott et al., 1987; Hickmott and Spear, 1992; Johnson, 1994; Kretz et al., 1999; Yang et al., 1999). However, the subject has been relatively little investigated because of the difficulty in obtaining uncontaminated trace element analyses and due to complications resulting from crystal chemistry and the composition of host minerals.

Micas are petrogenetically very useful minerals because of their high abundance in many metamorphic rocks, their wide range of stability, their relatively simple mineralogy and their potential to provide information about P-T conditions. To extract meaningful petrogenetic information, accurate measure-

\footnotetext{
*Author to whom correspondence should be addressed.
}

ment of the trace element partition coefficients for a wide range of trace elements in various metamorphic environments is essential. At present, there are relatively few published trace element partitioning studies for biotite-muscovite pairs in metamorphic systems (Butler, 1967; Moorbath et al., 1968; Dutrow et al., 1986; Shearer et al., 1986; Hervig and Peacock, 1989; Dahl et al., 1993; Domanik et al., 1993). Moreover, very little is known about the dependence of the biotite/muscovite distribution coefficients on the intensive and extensive variables, constraining geochemists to adopt a largely empirical approach using constant average distribution values in their modeling (e.g., Haack et al., 1984; Johnson, 1994). In addition, most trace element data in the earlier publications were obtained from bulk analyses of mineral separates, which have commonly proved to be contaminated with micro-inclusions of accessory minerals (Michael, 1988). The use of mineral separates also does not take mineral zoning into account, so the results may not yield equilibrium partition coefficients. These problems are especially acute in medium grade metamorphic rocks where micro-inclusions are ubiquitous. In this study, we have determined partition coefficients for selected trace elements in coexisting biotite and muscovite from ten metapelitic and quartzofeldspathic rocks from western Labrador using a microbeam technique and have examined the variation of biotite/muscovite partition coefficients as a function of crystal structure, variations in major element composition and metamorphic temperature. 


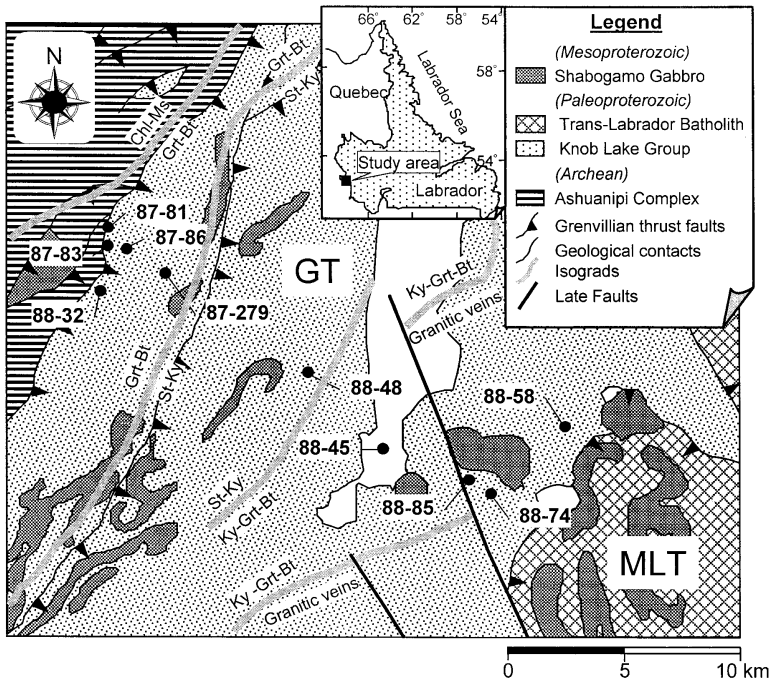

Fig. 1. Generalized geologic map of the northern Grenville province in western Labrador, Canada, showing metamorphic isograds and locations of the ten analyzed samples. GT-Gagnon terrane; MLT-Molson Lake terrane Geologic map from Connelly et al. (1996) and metamorphic isograds from Rivers (1983b) and van Gool (1992).

\section{GEOLOGY AND SAMPLES}

The ten analyzed samples come from Gagnon terrane in the Grenville Province of western Labrador (Fig. 1). Gagnon terrane comprises a metamorphic foreland fold-and-thrust belt (Rivers, 1983a,b; van Gool, 1992), that is separated from the Superior Province foreland in the northwest by the Grenville Front, and is tectonically overlain by Molson Lake terrane to the southeast. Metasediments in Gagnon terrane, which are part of the Paleoproterozoic Knob Lake Group, were deposited on the passive continental margin of the Superior Craton and experienced a single Barrovian-type regional metamorphism during the Grenvillian Orogeny at ca. $1000 \mathrm{Ma}$ (Rivers, 1983b; Brown et al., 1992; van Gool,1992; Rivers et al., 1993; Schwarz, 1998). During this orogenic event, Gagnon terrane was overthrust by Molson Lake terrane, composed of Late Paleoproterozoic to Mesoproterozoic granitoid and gabbroic rocks, and incorporated into the base of a major thrust wedge.
Metamorphic grade increases from greenschist facies in the northwest, at the Grenville Front, to upper amphibolite facies in the southeast, near Molson Lake terrane. Six metamorphic zones have been outlined by Rivers (1983b) based on the diagnostic mineral assemblages: chlorite-muscovite (I), biotitemuscovite (II), garnet-biotite (III), staurolite-kyanite (IV), biotite-kyanite-garnet (V) and biotite-kyanite-garnet-granitic veins (VI) in order of increasing metamorphic grade (Fig. 1). The isograds were telescoped during thrusting (van Gool, 1992), and the apparent absence of a staurolite-biotite zone between the garnet-biotite and staurolite-kyanite zones may be due either to telescoping and/or to poor exposure. The samples chosen for this study include five from the garnet-biotite zone (referred to as low-T samples) and another five from staurolitekyanite, biotite-kyanite-garnet and biotite-kyanite-garnet-granitic veins zones (referred to as high-T samples). Micas from the lowest grade zone are very fine grained, presenting difficulties for the LAM-ICP-MS technique, and were not included in this study.

All selected rocks are foliated and are composed principally of quartz (26-62\% modal), micas (35-54\% modal) and lesser amounts of garnet, kyanite, chlorite, epidote and plagioclase, with accessory minerals constituting the remainder (Table 1). All of the samples have at least one Ti-saturating phases such as ilmenite and rutile in the matrix. Plagioclase occurs in all samples except 88-58. Accessory minerals in the samples include pyrite, ilmenite, rutile, monazite, apatite, tourmaline, graphite and zircon. Both biotite and muscovite show little sign of retrogression and secondary muscovite rarely occurs in these rocks. Inclusions of apatite, zircon and ilmenite are common in the biotite crystals, and, to a lesser extent, in the white mica. A marked coarsening of the grain size of the micas occurs within the staurolite-kyanite zone and coincides with the disappearance of primary chlorite from the assemblage (Table 1). Mineral assemblages, textures and reactions in metapelitic rocks of the Gagnon terrane in western Labrador are described in detail elsewhere (e.g., Rivers, 1983b; van Gool, 1992).

\section{ANALYTICAL METHODS}

\subsection{Electron Microprobe Analysis}

Major and minor element analyses were performed using the Cameca ${ }^{\circledR}$ SX-50 electron microprobe at Memorial University

Table 1. Mineral assemblages and modal percentages of the ten metapelitic samples from western Labrador.

\begin{tabular}{|c|c|c|c|c|c|c|c|c|c|c|c|c|c|c|c|c|c|}
\hline Sample & Zones & Qtz & Ms & $\mathrm{Bt}$ & Chl & Ep & $\mathrm{Pl}$ & Ky & Grt & Tur & Ap & Rt & Zrn & $\mathrm{Ilm}$ & Py & Mo & $\mathrm{Gr}$ \\
\hline $87-81$ & III & 41 & 28 & 26 & & & $<1$ & & $<1$ & $<1$ & $<1$ & $<1$ & $<1$ & $<1$ & $<1$ & & \\
\hline $87-83$ & III & 53 & 11 & 28 & $<1$ & $<1^{\mathrm{a}}$ & $<1$ & & 4 & $<1$ & $<1$ & & $<1$ & $<1$ & & & $<1$ \\
\hline $87-86$ & III & 40 & 11 & 43 & $<1$ & $<1^{\mathrm{a}}$ & $<1$ & & $<1$ & $<1$ & $<1$ & & $<1$ & $<1$ & & & $<1$ \\
\hline $87-279$ & III & 48 & 16 & 23 & $4^{b}$ & $<1$ & $<1$ & & 3 & & $<1$ & $<1$ & $<1$ & $<1$ & $<1$ & & $<1$ \\
\hline $88-32$ & III & 30 & 19 & 35 & $<1$ & $<1^{\mathrm{a}}$ & $<1$ & & 10 & $<1$ & $<1$ & & $<1$ & $<1$ & & & \\
\hline $88-48$ & IV & 26 & 10 & 44 & $4^{\mathrm{b}}$ & & $<1$ & 2 & 10 & $<1$ & & $<1$ & $<1$ & $<1^{\mathrm{a}}$ & $<1$ & & \\
\hline $88-45$ & V & 44 & 27 & 11 & & & $<1$ & $<1$ & 11 & & & $<1$ & $<1$ & & $<1$ & $<1$ & \\
\hline $88-85$ & V & 62 & 29 & 6 & & & $<1$ & 2 & $<1$ & & $<1$ & $<1$ & $<1$ & $<1$ & $<1$ & $<1^{\mathrm{a}}$ & \\
\hline $88-74$ & VI & 34 & 26 & 23 & & & 5 & 9 & $<1$ & $<1$ & $<1$ & $<1^{\mathrm{a}}$ & $<1$ & $<1$ & $<1$ & $<1$ & \\
\hline $88-58$ & VI & 34 & 43 & 8 & & & & & 11 & & $<1$ & $<1$ & $<1$ & $<1$ & & $<1$ & \\
\hline
\end{tabular}

${ }^{\text {a }}$ Minerals occur only as inclusions in garnet.

${ }^{\mathrm{b}}$ Secondary minerals. Characteristic mineral assemblages of metamorphic zones are: III; Grt-Bt, IV; St-Ky; V; Bt-Ky-Grt and VI; Bt-Ky-Grt granitic veins. Mineral abbreviations after Kretz (1983). 
Table 2. Precision and mean values for a glass standard BCR-2 determined by LAM-ICP-MS.

\begin{tabular}{|c|c|c|c|c|c|c|c|}
\hline Elements & AVG & STD & RSD & $\mathrm{DL}$ & No & Known & AVG/Known \\
\hline $\mathrm{Li}$ & 8.4 & & & 5.955 & 1 & 9.98 & 0.84 \\
\hline $\mathrm{Sc}$ & 31.4 & 0.8 & $2 \%$ & 0.653 & 5 & 32.6 & 0.96 \\
\hline $\mathrm{TiO}_{2}$ & 2.05 & 0.04 & $2 \%$ & $1.6 \mathrm{E}-4$ & 10 & 2.24 & 0.91 \\
\hline $\mathrm{V}$ & 402 & 11 & $3 \%$ & 0.068 & 7 & 407 & 0.99 \\
\hline $\mathrm{Cr}$ & 15.0 & 2.5 & $16 \%$ & 2.501 & 6 & 16 & 0.94 \\
\hline $\mathrm{MnO}$ & 0.18 & 0.01 & $4 \%$ & $5.1 \mathrm{E}-5$ & 7 & 0.177 & 1.03 \\
\hline $\mathrm{Co}$ & 36.4 & 1.7 & $5 \%$ & 0.325 & 7 & 37 & 0.98 \\
\hline $\mathrm{Ni}$ & 11.3 & 1.4 & $12 \%$ & 1.041 & 7 & 13 & 0.87 \\
\hline $\mathrm{Cu}$ & 20.5 & 1.0 & $5 \%$ & 0.356 & 5 & 19 & 1.08 \\
\hline $\mathrm{Zn}$ & 173 & 12 & $7 \%$ & 0.581 & 5 & 129.5 & 1.33 \\
\hline $\mathrm{Rb}$ & 54 & & & 0.018 & 2 & 47.51 & 1.14 \\
\hline $\mathrm{Sr}$ & 337.2 & 7.6 & $2 \%$ & 0.006 & 5 & 337 & 1.00 \\
\hline Y & 31.9 & 1.7 & $5 \%$ & 0.007 & 7 & 32.51 & 0.98 \\
\hline $\mathrm{Zr}$ & 170.5 & 6.3 & $4 \%$ & 0.021 & 10 & 184.4 & 0.92 \\
\hline $\mathrm{Nb}$ & 10.8 & 1.0 & $9 \%$ & 0.006 & 5 & 13.14 & 0.82 \\
\hline Cs & 1.3 & & & 0.014 & 2 & 1.19 & 1.09 \\
\hline $\mathrm{Ba}$ & 644 & 21 & $3 \%$ & 0.035 & 10 & 681 & 0.95 \\
\hline $\mathrm{La}$ & 25.5 & 1.1 & $4 \%$ & 0.005 & 7 & 25.3 & 1.01 \\
\hline $\mathrm{Ce}$ & 54.3 & 1.7 & $3 \%$ & 0.003 & 9 & 53.6 & 1.01 \\
\hline Hf & 4.8 & 0.3 & $5 \%$ & 0.021 & 7 & 5.17 & 0.94 \\
\hline $\mathrm{Ta}$ & 0.6 & 0.1 & $9 \%$ & 0.004 & 7 & 0.78 & 0.77 \\
\hline
\end{tabular}

Based on 10 determinations over the period March 19, 1996 to April 5, 1997. AVG = average; STD = standard deviation; RSD = relative standard deviation; DL = detection limits; No = number of observations; and Known = literature values from Govindaraju (1994).

of Newfoundland using energy dispersive (ED) and wavelength dispersive (WD) methods simultaneously. Analyses were carried out using a $15 \mathrm{kV}$ accelerating voltage, $10 \mathrm{nA}$ current and a 5 micron beam diameter. ED analyses used a cobalt gain calibration. Ti, $\mathrm{F}$ and $\mathrm{Cl}$ were determined by WD analysis using ilmenite, apatite and tugtupite $\left(\mathrm{Na}_{4} \mathrm{AlBeSi}_{4} \mathrm{O}_{12} \mathrm{Cl}\right)$ as standards, respectively. Analyses were obtained on three or more crystals of biotite and muscovite in each of the ten samples. Precision at the $1 \sigma$ level for Ti (used for calibration of ICP-MS results, see below) was better than $6 \%$ relative in both biotite and muscovite.

\subsection{LAM-ICP-MS Analysis}

Trace element compositions in micas were determined by a laser ablation system coupled to an ICP-MS (Fisons VG PQII $\left.+\mathrm{S}^{\circledR}\right)$ at Memorial University of Newfoundland. The LAM system incorporates a Nd:YAG laser (266 nm wavelength), a custom built sample cell and an Ar carrier gas system. Details of the system are described in Jackson et al. (1992), Jenner et al. (1994) and Taylor et al. (1997).

Data acquisition was performed by peak jumping in pulse counting mode, acquiring individual intensity data for each analyte isotope during each mass spectrometer sweep ( $\sim 1 \mathrm{sec})$. A total of about 480 sweeps, comprising a gas background interval of about 200 sweeps followed by an ablation interval of about 280 sweeps was performed for each analysis. Calibration was conducted on the NIST SRM-610 glass standard, and BCR-2 was used to check the data quality during each run. Ti was routinely employed as the internal standard, based on electron microprobe measurement of the $\mathrm{TiO}_{2}$ contents in the micas.

Data reduction followed the protocol outlined by Longerich et al. (1996). Limit of detection for BCR-2 for a $\sim 50 \mu \mathrm{m}$ beam size and $\sim 0.5 \mathrm{~mJ} /$ pulse was typically in the range $3-35 \mathrm{ppb}$ for most high-mass elements ( $\mathrm{Rb}$ to $\mathrm{Ta}$ ), and between 68 and 6000 ppb for lower-mass elements ( $\mathrm{Li}$ to $\mathrm{Zn}$ ) (Table 2). However, detection limits for samples are different from the glass standard because of different beam diameters, counting times and ablation energy used for each single analysis. For high-T micas, we used a $\sim 70 \mu \mathrm{m}$ beam size and $\sim 0.7 \mathrm{~mJ} /$ pulse of laser energy. For low-T micas, we had to reduce the beam size and pulse energy by almost half because of their smaller size. According to Longerich et al. (1996), the difference in beam size between low- and high-T micas results in at least a fourfold increase in the detection limit.

Repeated measurements of BCR-2 glass at the same ablation conditions yielded a precision $(1 \sigma)$ of better than 5 and $10 \%$ relative for absolute concentrations above and below $1 \mathrm{ppm}$, respectively, except for $\mathrm{Cr}$ and $\mathrm{Ni}$. The poor precision obtained for $\mathrm{Cr}$ and $\mathrm{Ni}$ is attributed to their concentrations approaching detection limits in the glass. $\mathrm{Zn}$ analyses clearly show the effects of fractionation during the laser ablation, as indicated by increasing signals over time, invariably resulting in higher concentrations compared to the literature values (Table 2). Because of the fractionation effect observed, the lowest measured value of $\mathrm{Zn}$ for each sample was used.

The time-resolved analysis of the LAM allows detection of zoning and inclusions in the analyzed mineral grain during ablation, which is a great advantage over other microbeam techniques such as PIXE and SIMS. However, the presence of submicroscopic inclusions below the resolution of the time-resolved signal (a few microns) cannot be ruled out. Indeed, Zr, La and $\mathrm{Ce}$ analyses of micas are highly variable on a thin-section scale. Since micro-inclusion phases enriched in $\mathrm{Zr}$, La and $\mathrm{Ce}$, such as zircon, monazite and apatite, were found in the analyzed micas, we consider the most reliable data to be those with the lowest concentrations of these elements. $\mathrm{Zn}, \mathrm{Zr}$, La and Ce data therefore should be considered as only semi-quantitative.

Electron microprobe and LAM-ICP-MS analyses of biotite 


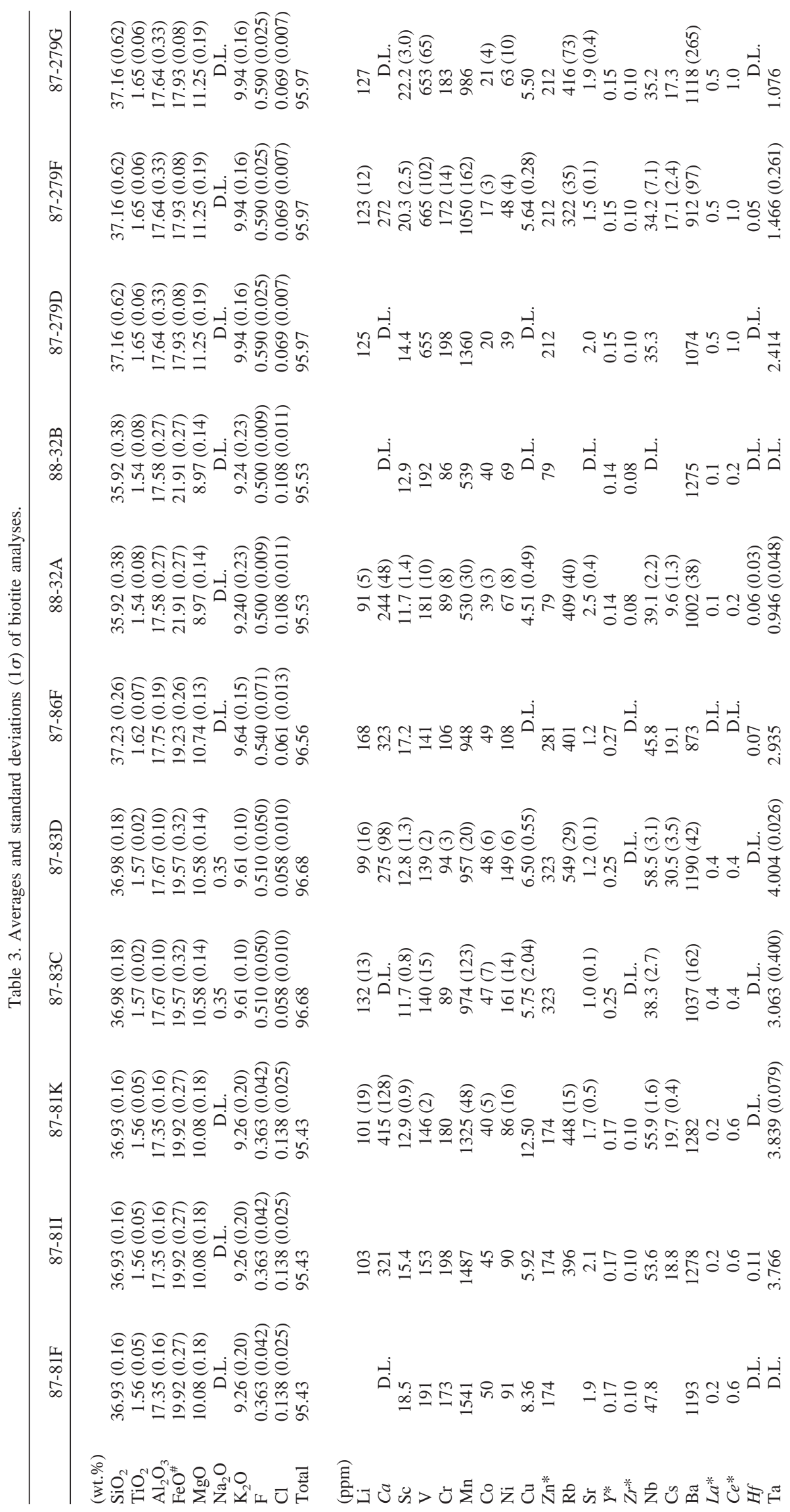




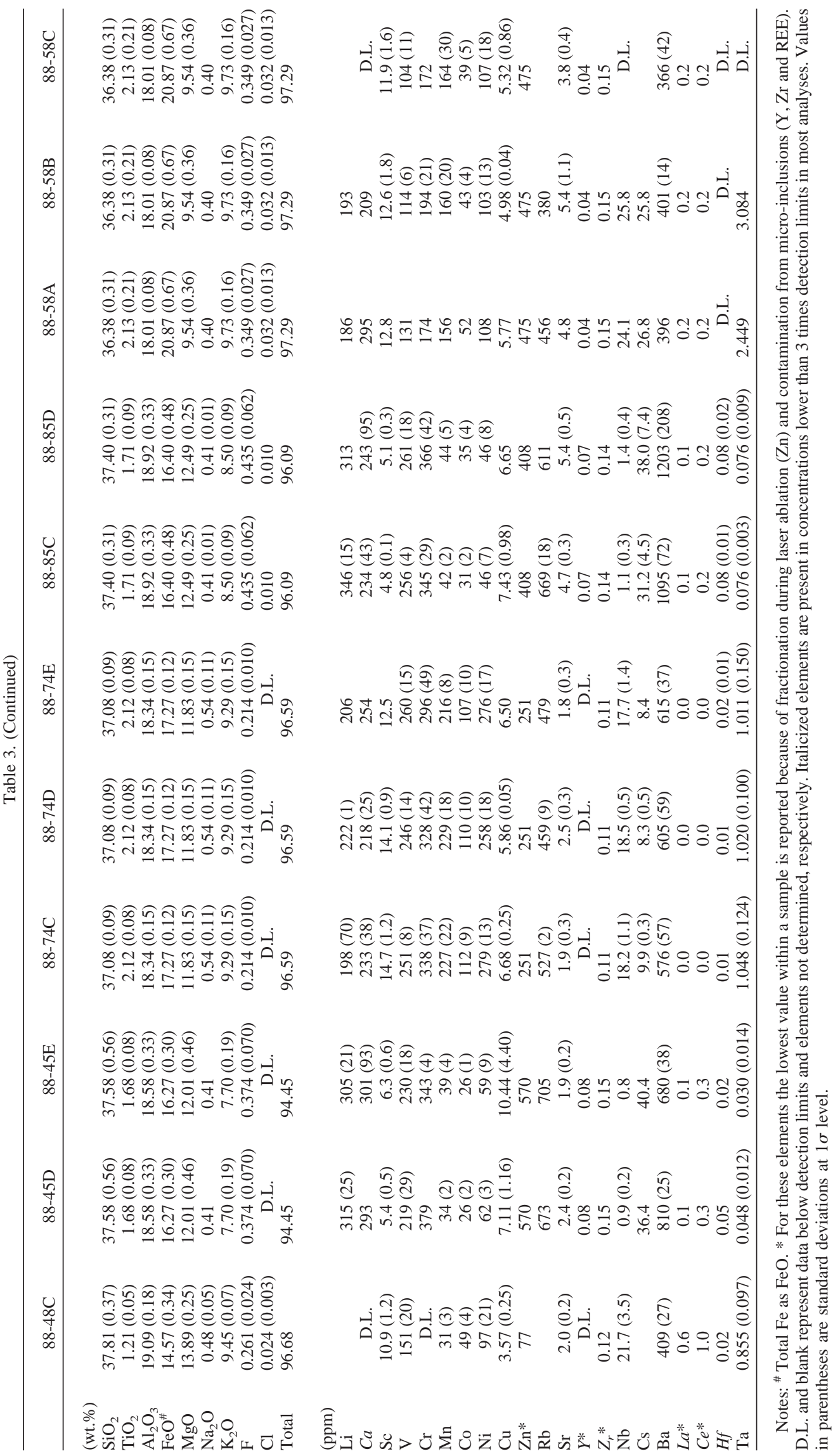




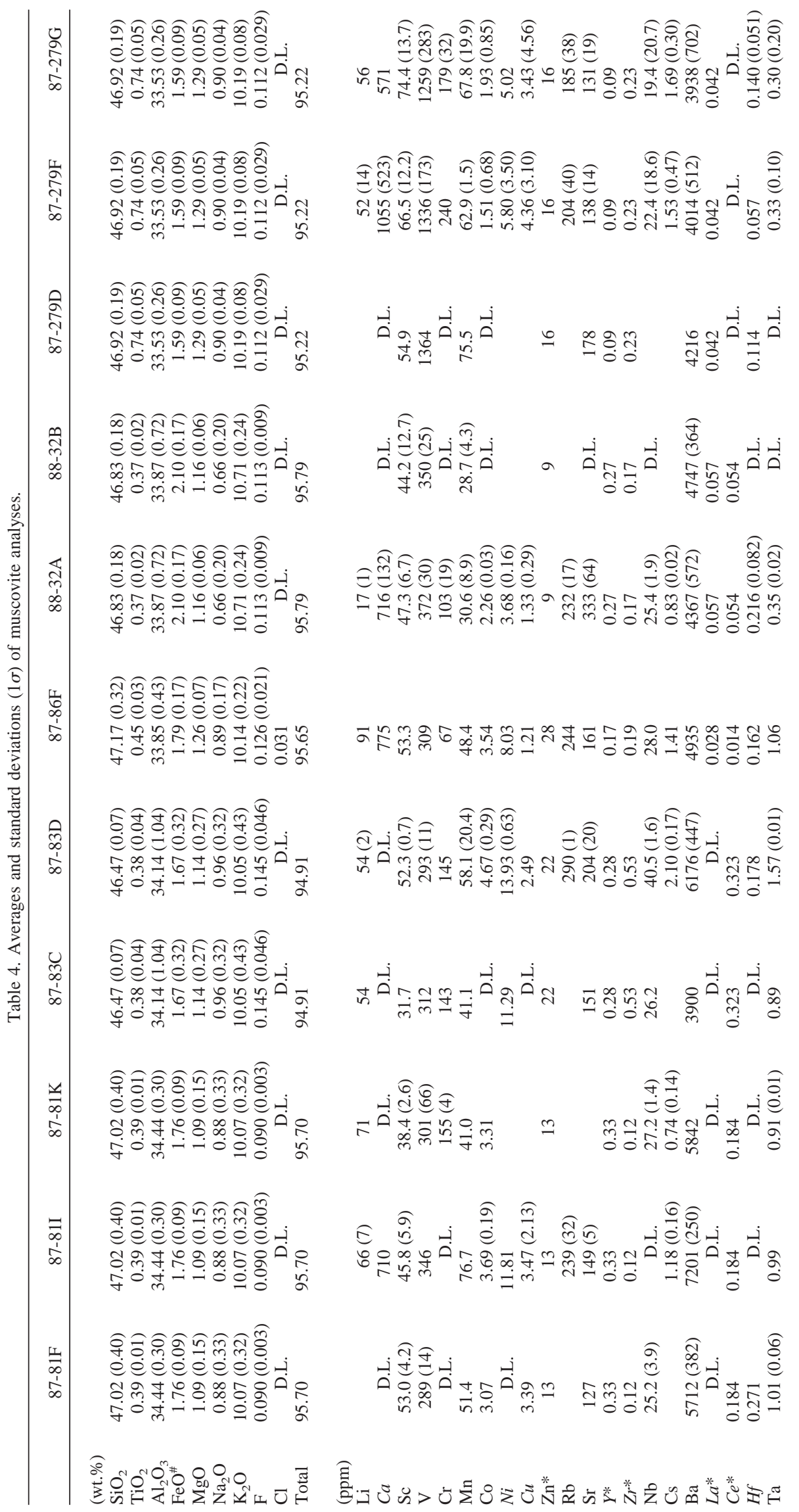




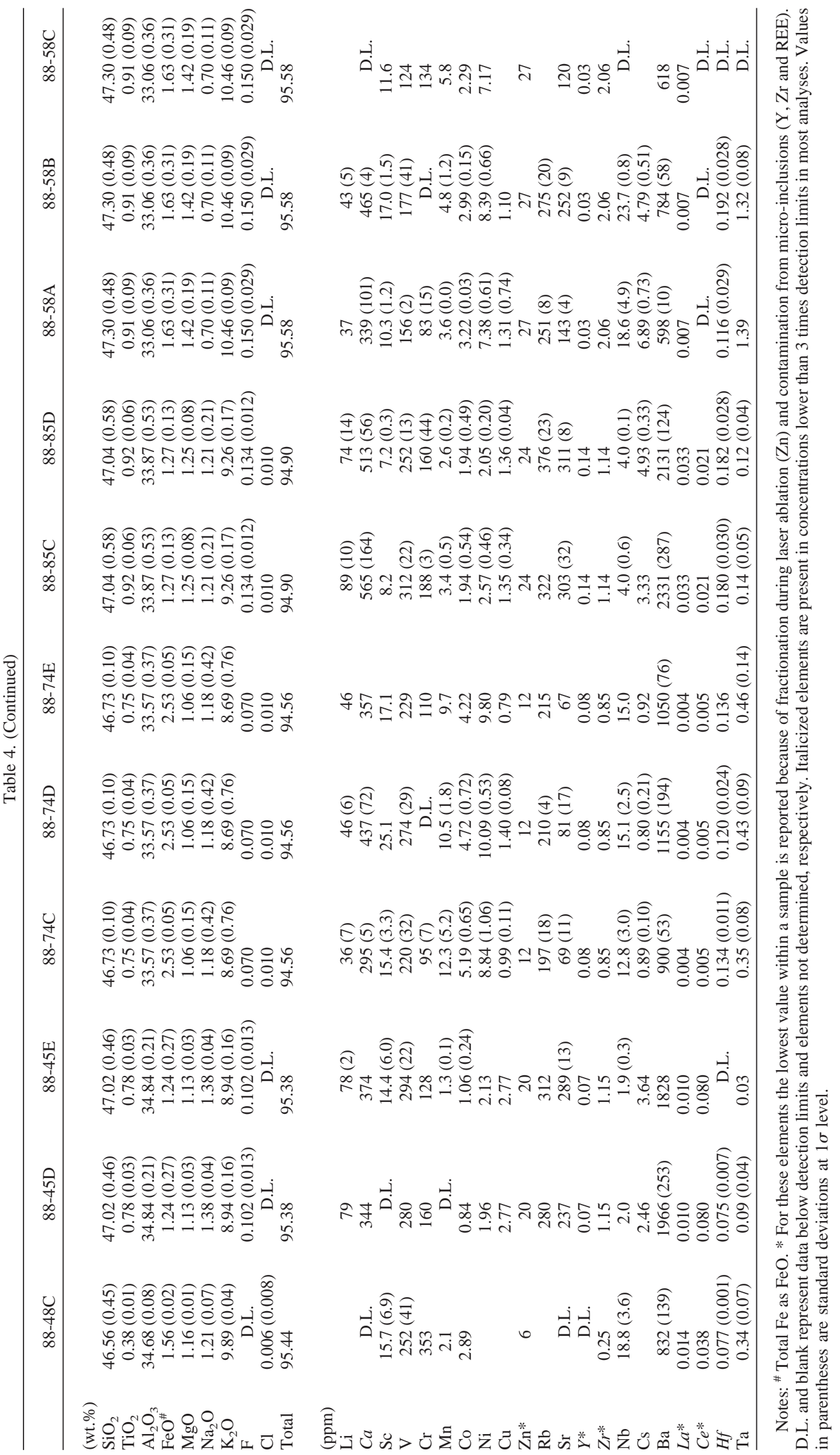




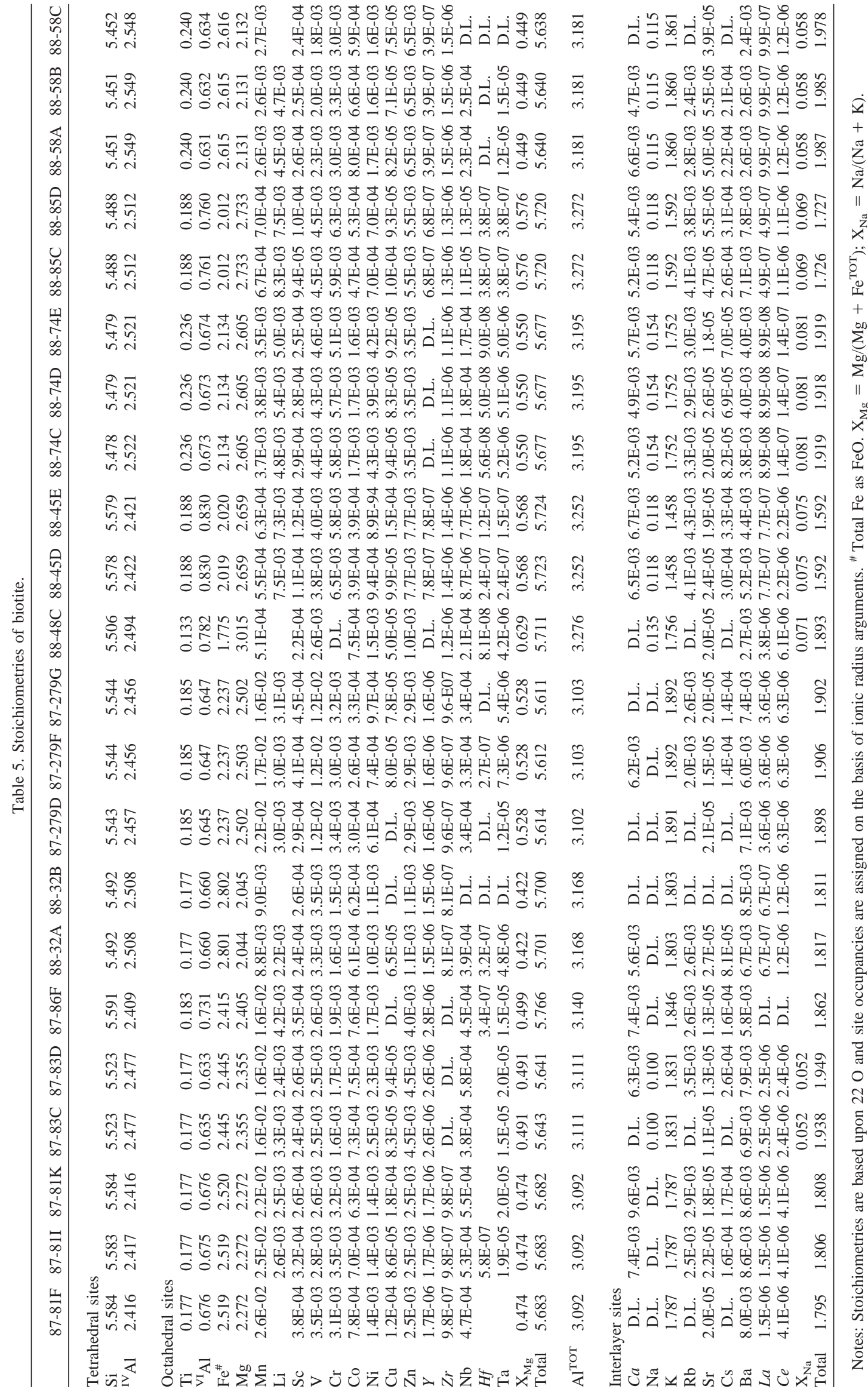




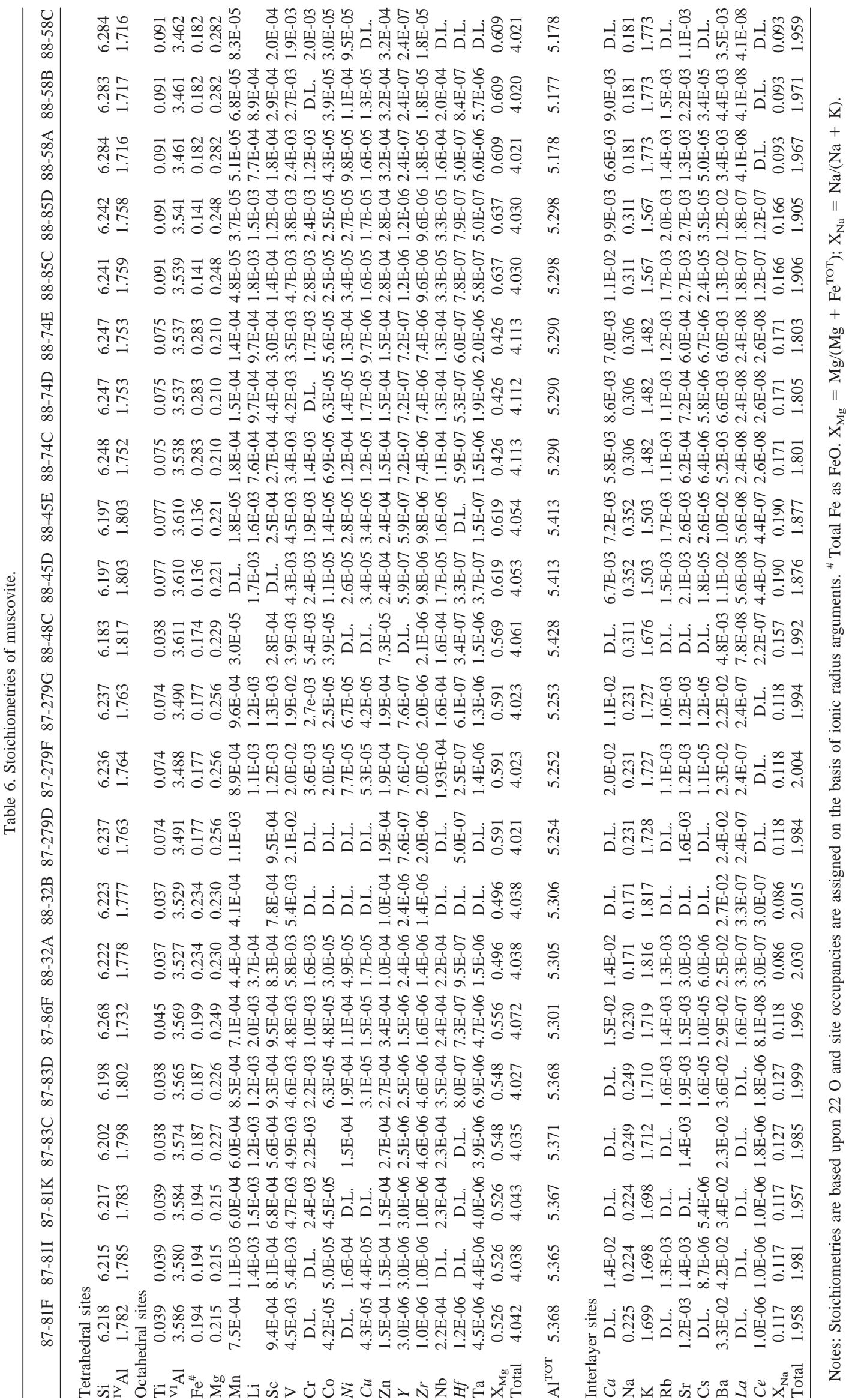



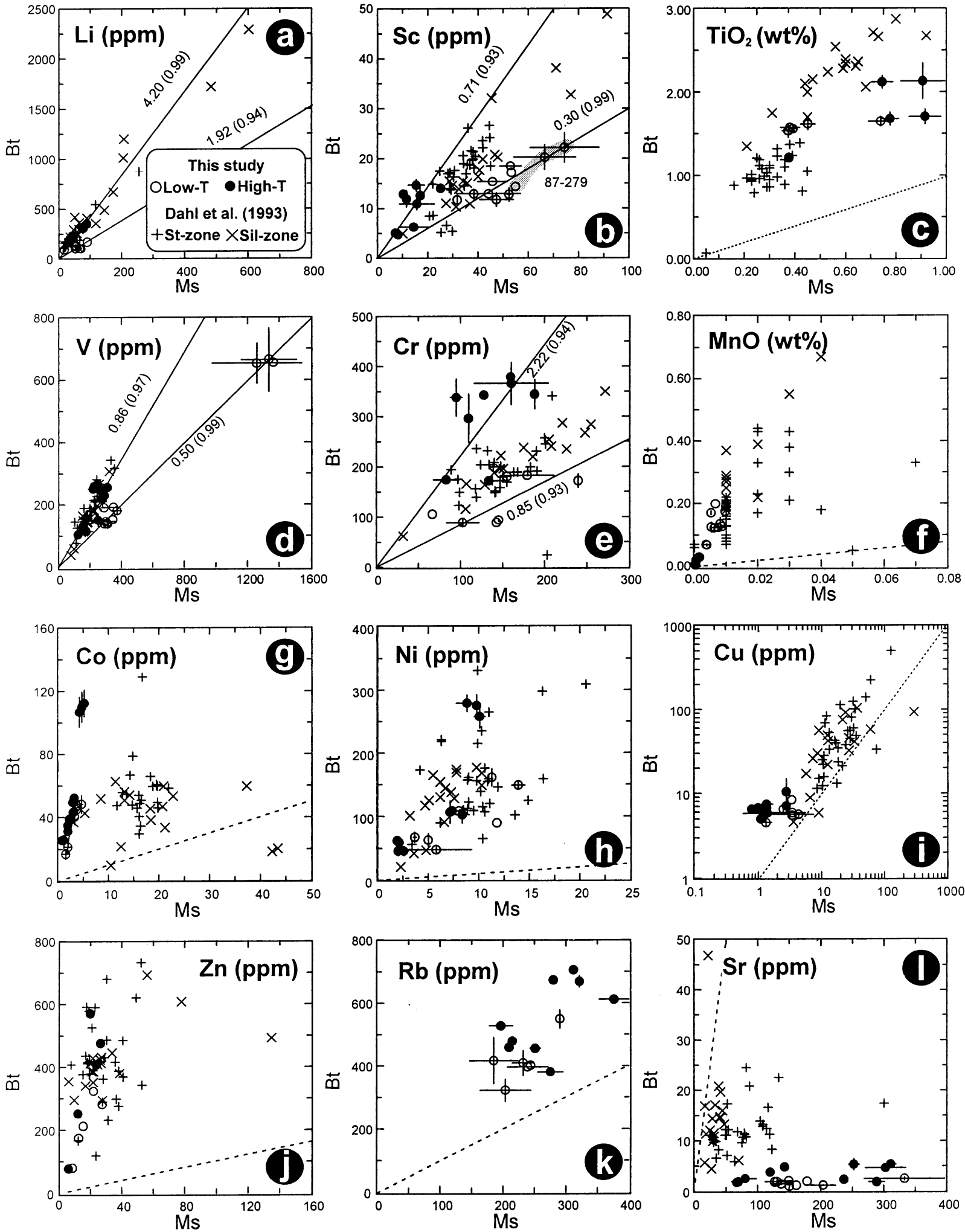

Fig. 2. Distribution diagrams showing the partitioning of elements between coexisting biotite (Bt) and muscovite (Ms). Open and closed circles represent low and high-T biotite-muscovite pairs, respectively. + and $\times$ represent mica pairs from St and Sil-zone, reported by Dahl et al. (1993). Error bars represent the standard deviation at $1 \sigma$. Data are regressed where they show systematic differences between low and high-T. The numbers are slopes of regression lines, with values in parentheses representing $\mathrm{r}^{2}$. Dashed lines represent equal partitioning. Labeled data points are discussed in the text. 

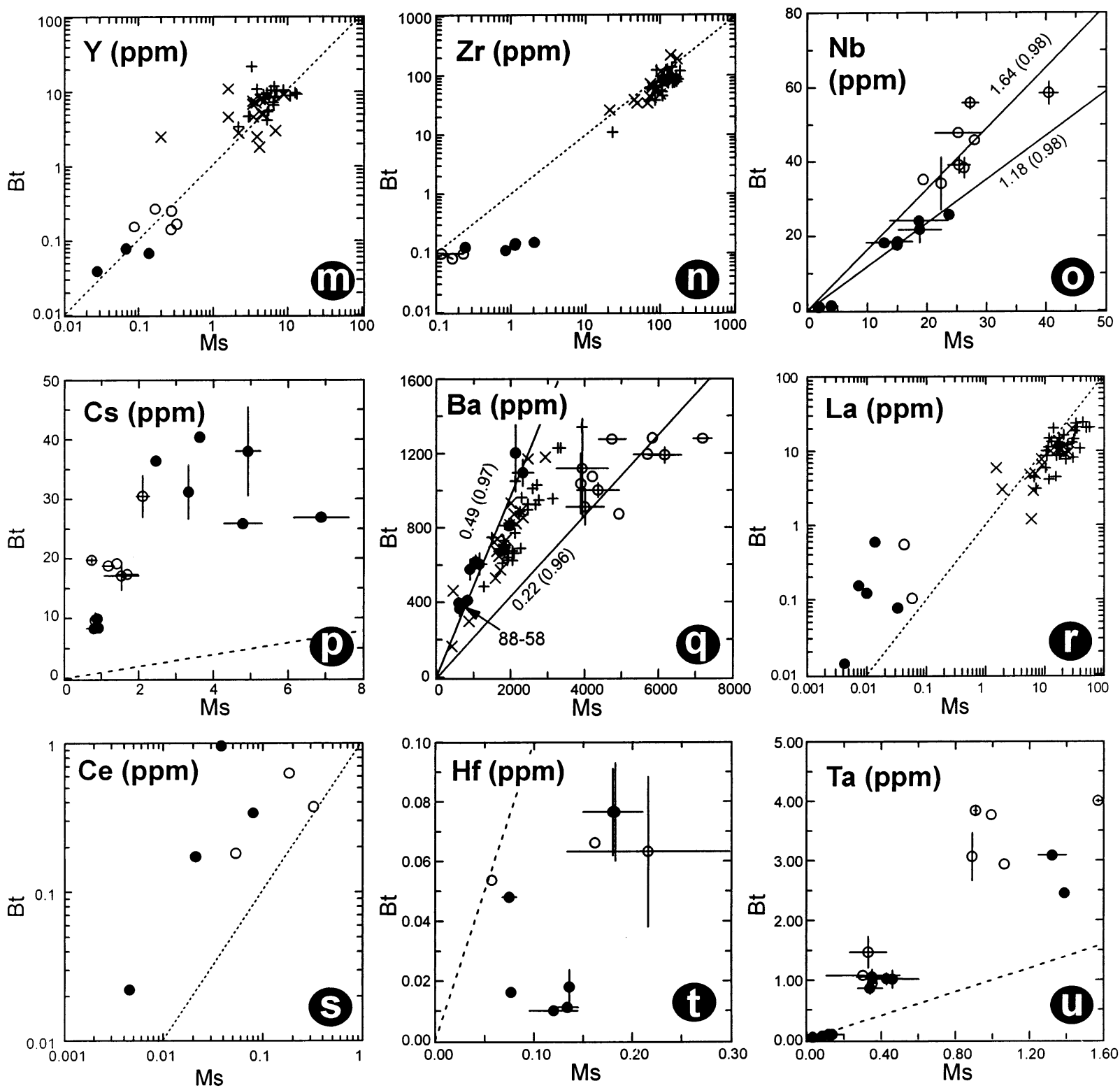

Fig. 2. (Continued)

and muscovite are presented in Tables 3-4 as averages and standard deviations $(1 \sigma)$ of $2-3$ analyses performed for each mineral from two to three domains in a thin-section, except for sample 87-86, in which all analyses come from a single domain. Most analyses of $\mathrm{Ca}, \mathrm{Y}, \mathrm{Zr}, \mathrm{La}, \mathrm{Ce}$ and $\mathrm{Hf}$ in biotite and $\mathrm{Ca}, \mathrm{Ni}, \mathrm{Cu}, \mathrm{Y}, \mathrm{Zr}, \mathrm{La}, \mathrm{Ce}$ and $\mathrm{Hf}$ in muscovite are close to their respective lower limits of detection $(<3$ times detection limit) and these elements are italicized in the Tables 3-4. Mica stoichiometries are given in Tables 5-6. Cation site-occupancies were assigned on the basis of ionic radii (Shannon, 1976).

Establishing the presence or absence of zoning is important for an evaluation of chemical equilibrium. Each mineral, therefore, was analyzed close to its rim and at the core for representative samples. The analyzed micas are virtually unzoned both in major and trace element concentrations. Care was taken to avoid obvious cleavages during laser ablation, but cleavage does not appear to affect analytical results.

\section{MAJOR ELEMENT COMPOSITIONS}

Structural formulae for both biotite and muscovite are based on 22 oxygen atoms (Tables 5-6). Both biotite and muscovite show no significant variation in $\mathrm{Si}$ and thus $\mathrm{Al}^{\mathrm{IV}}$ content, which is defined as the difference between 8.0 and the number of $\mathrm{Si}$ atoms. All of our micas are saturated with respect to Ti because of their coexistence with either ilmenite or rutile. In the case of $\mathrm{Al}$, micas from high-T samples, except for sample $88-58$, are saturated in Al because of the presence of kyanite in the matrix (Tables 5-6). However, there are no Al-saturating phases in the low-T samples. $\mathrm{Fe}^{3+} / \mathrm{Fe}^{2+}$ ratios in biotite and muscovite were 
Table 7. Molar partition coefficients $\left(\mathrm{D}_{\mathrm{i}}^{*}\right)$ of coexisting biotite-muscovite pairs from metapelites, western Labrador.

\begin{tabular}{|c|c|c|c|c|c|c|c|c|c|c|c|}
\hline$\underline{\text { Elements }}$ & $87-81 \mathrm{~F}$ & $87-81 \mathrm{I}$ & $87-81 \mathrm{~K}$ & $87-83 \mathrm{C}$ & 87-83D & $87-86 \mathrm{~F}$ & $88-32 \mathrm{~A}$ & 88-32B & 87-279D & $87-279 \mathrm{~F}$ & $87-279 G$ \\
\hline \multicolumn{12}{|c|}{ Octahedral sites } \\
\hline $\mathrm{Li}$ & & 1.18 & 1.09 & 1.80 & $1.37(0.23)$ & 1.40 & $4.01(0.28)$ & & & $1.77(0.51)$ & 1.69 \\
\hline $\mathrm{Sc}$ & 0.27 & 0.25 & $0.26(0.02)$ & 0.27 & $0.18(0.02)$ & 0.25 & $0.19(0.03)$ & 0.22 & 0.20 & $0.23(0.05)$ & $0.22(0.05)$ \\
\hline V & 0.50 & 0.33 & $0.37(0.08)$ & 0.33 & $0.35(0.01)$ & 0.35 & $0.37(0.04)$ & 0.42 & 0.36 & $0.37(0.07)$ & $0.39(0.09)$ \\
\hline $\mathrm{Cr}$ & & & 0.88 & 0.46 & 0.48 & 1.21 & $0.66(0.14)$ & & & 0.53 & 0.76 \\
\hline Co & 12.26 & 9.25 & 9.26 & & $7.67(1.01)$ & 10.43 & $13.22(0.95)$ & & & $8.41(4.12)$ & $8.29(3.98)$ \\
\hline$N i$ & & 5.77 & & 10.59 & $7.95(0.48)$ & 10.24 & $13.97(1.82)$ & & & $6.12(3.73)$ & 9.31 \\
\hline $\mathrm{Cu}$ & 1.87 & 1.30 & & & 1.94 & & $2.59(0.64)$ & & & $0.96(0.68)$ & 1.19 \\
\hline $\mathrm{Zn}$ & 10.46 & 10.46 & 10.46 & 10.89 & 10.89 & 7.73 & 7.02 & 7.01 & 10.18 & 10.12 & 10.12 \\
\hline$Y$ & 0.39 & 0.39 & 0.39 & 0.67 & 0.67 & 1.21 & 0.40 & 0.40 & 1.32 & 1.31 & 1.31 \\
\hline $\mathrm{Zr}$ & 0.62 & 0.62 & 0.62 & & & & 0.37 & 0.37 & 0.31 & 0.31 & 0.31 \\
\hline $\mathrm{Nb}$ & 1.44 & & $1.56(0.09)$ & 1.09 & $1.07(0.07)$ & 1.25 & $1.18(0.11)$ & & & 1.14 & 1.35 \\
\hline$H f$ & & & & & & 0.31 & $0.22(0.12)$ & & & 0.70 & \\
\hline $\mathrm{Ta}$ & & 2.88 & $3.21(0.08)$ & 2.56 & $1.89(0.01)$ & 2.10 & $2.04(0.14)$ & & & $3.31(1.15)$ & 2.65 \\
\hline \multicolumn{12}{|c|}{ Interlayer sites } \\
\hline $\mathrm{Rb}$ & & 1.89 & & & $2.11(0.11)$ & 1.88 & $2.02(0.25)$ & & & $1.76(0.40)$ & $2.51(0.68)$ \\
\hline $\mathrm{Sr}$ & 0.02 & 0.02 & & 0.01 & $0.01(0.001)$ & 0.01 & $0.01(0.002)$ & & 0.01 & $0.01(0.002)$ & $0.02(0.004)$ \\
\hline Cs & & 18.12 & $30.50(5.93)$ & & $16.14(2.31)$ & 15.46 & $13.27(1.84)$ & & & $12.43(4.18)$ & 11.44 \\
\hline $\mathrm{Ba}$ & 0.24 & 0.20 & 0.25 & 0.30 & $0.21(0.02)$ & 0.20 & $0.26(0.04)$ & 0.31 & 0.29 & $0.25(0.04)$ & $0.32(0.09)$ \\
\hline $\mathrm{La}$ & & & & & & & 2.04 & 2.04 & 14.55 & 14.46 & 14.45 \\
\hline $\mathrm{Ce}$ & 3.90 & 3.90 & 3.90 & 1.29 & 1.29 & & 3.86 & 3.86 & & & \\
\hline $\mathrm{T}\left({ }^{\circ} \mathrm{C}\right)$ & 507 & 507 & 507 & 492 & 492 & 503 & 503 & 503 & 530 & 530 & 530 \\
\hline $\mathrm{P}$ (kbar) & 7.6 & 7.6 & 7.6 & 7.7 & 7.7 & 7.4 & 8.8 & 8.8 & 8.8 & 8.8 & 8.8 \\
\hline
\end{tabular}

Italicized elements are present in concentrations below or close to 3 times detection limits in either biotite or muscovite. Metamorphic temperatures and pressures were estimated using the garnet-biotite geothermometer of Holdaway et al. (1997), and Grt-Pl-Bt-Ms and Grt-Ky-Qtz-Pl geobarometers of Hodges and Crowley (1985).

not determined, precluding full evaluation of the variation of trace element distributions involving iron.

\subsection{Biotite}

The majority of the VI-fold sites are filled by $\mathrm{Mg}$ (2.04-3.01 atoms per formula unit, p.f.u.) and $\mathrm{Fe}^{\mathrm{TOT}}$ (1.77-2.80 atoms p.f.u.) (Table 5). $\mathrm{X}_{\mathrm{Mg}}$ of biotite, ranging from 0.42 to 0.64 , reflects variation both in the bulk composition and $\mathrm{T}$. Octahedral $\mathrm{Al}$ in biotite, defined as the difference between $\mathrm{Al}^{\mathrm{TOT}}$ and ${ }^{\mathrm{IV}} \mathrm{Al}$, is between 0.63 and 0.83 atoms p.f.u. Most of the $\mathrm{Al}^{\mathrm{IV}}$ is balanced by $\mathrm{Al}^{\mathrm{VI}}$, suggesting operation of the Al-Tschermaks substitution, $(\mathrm{Fe}, \mathrm{Mg}) \mathrm{SiAl}_{-1}^{\mathrm{VI}} \mathrm{Al}_{-1}^{\mathrm{IV}}$. Biotite coexisting with kyanite is relatively enriched in $\mathrm{Al}^{\mathrm{TOT}}(3.18-3.28)$ compared to low-T biotite (3.09-3.17), presumably due to Al saturation in the former samples (Table 5). Ti contents in biotite range from 0.13 to 0.24 atoms p.f.u. with no clear correlation with the contents of $\mathrm{Fe}$ and $\mathrm{Mg}$ and metamorphic grade (Table 5). Concentrations of $\mathrm{Mn}$ are typically low, but vary widely (31$1,541 \mathrm{ppm})$. In all of the biotites studied, the sum of the octahedral cations is below the theoretical value of six atoms p.f.u., but is always above 5.61, implying no significant amount of $\mathrm{Fe}^{3+}$ in the biotites.

Theoretically, two atoms p.f.u. are allocated to the XIIinterlayer site in biotite. The XII- site in the analyzed biotites is dominated by $\mathrm{K}$ (1.46-1.89 atoms p.f.u.) with small amounts of $\mathrm{Na}(0.10-0.15$ atoms p.f.u. $)$ and $\mathrm{Ca}(<0.01$ atoms p.f.u. $)$ (Table 5). The amount of interlayer site vacancy, ranging from 0.02 to 0.41 atoms p.f.u., is surprising given the almost complete analyses. Concentrations of $\mathrm{F}$ in biotite range between
0.10 and 0.28 atoms p.f.u. $\mathrm{Cl}$ contents are uniformly low $(<0.04$ atoms p.f.u. $)$.

\subsection{Muscovite}

$\mathrm{Al}^{\mathrm{VI}}$ of muscovite varies from 3.46 to 3.61 atoms p.f.u. with the lowest value from the high grade sample 88-58. Al comprises $88 \%$ of the ions on average in the octahedral sites, the remainder being mostly $\mathrm{Mg}$ (0.21-0.28 atoms p.f.u.) and $\mathrm{Fe}^{\mathrm{TOT}}$ (0.14-0.28 atoms p.f.u.). The muscovite compositions deviate slightly from the ideal Al-Tschermak substitution when defined in terms of $\mathrm{Si}$ and $\mathrm{Al}^{\mathrm{TOT}}$. However, the linear distribution of analyses parallel to the Al-Tschermak substitution (not shown) indicates no significant variations in $\mathrm{Fe}^{3+}$ contents among the analyzed muscovites. With the exception of sample $88-58$ (which does not contain kyanite), the content of $\mathrm{Al}^{\mathrm{TOT}}$ of muscovite from high-T samples is similar to that of low-T samples, indicating quasi-saturation of $\mathrm{Al}$ in low- $\mathrm{T}$ samples. The Ti contents of muscovite range from 0.04 to 0.09 cations p.f.u., and correlate positively with the $\mathrm{Mg}$ content. The $\mathrm{Mn}$ content of all muscovites studied is extremely low (1.3-76.7 $\mathrm{ppm}$ ) and appears to decrease with metamorphic grade. The total octahedral occupancy of analyzed muscovites (ideally 4.00 atoms p.f.u.) varies from 4.02 to 4.11 atoms p.f.u., indicating slight deviation from dioctahedral micas in all analyses.

The XII interlayer site in white mica is filled predominantly by $\mathrm{K}$ (1.48-1.82 atoms p.f.u.) and by lesser amounts of $\mathrm{Na}$ (0.17-0.35 atoms p.f.u.). The Ca content determined by LAMICP-MS is negligible (mostly below detection limits, occasion- 
Table 7. (Continued)

\begin{tabular}{|c|c|c|c|c|c|c|c|c|c|c|c|}
\hline Elements & $88-48 \mathrm{C}$ & $88-45 \mathrm{D}$ & $88-45 \mathrm{E}$ & $88-74 \mathrm{C}$ & 88-74D & $88-74 \mathrm{E}$ & $88-85 \mathrm{C}$ & $88-85 \mathrm{D}$ & $88-58 \mathrm{~A}$ & $88-58 B$ & $88-58 \mathrm{C}$ \\
\hline \multicolumn{12}{|c|}{ Octahedral sites } \\
\hline $\mathrm{Li}$ & & 2.98 & $2.93(0.22)$ & $4.04(1.64)$ & $3.58(0.49)$ & 3.32 & $2.86(0.34)$ & 3.09 & 3.78 & 3.40 & \\
\hline $\mathrm{Sc}$ & $0.51(0.23)$ & & $0.32(0.14)$ & $0.70(0.16)$ & 0.41 & 0.54 & 0.43 & $0.52(0.04)$ & 0.93 & $0.55(0.09)$ & 0.77 \\
\hline V & $0.44(0.09)$ & 0.59 & $0.59(0.06)$ & $0.84(0.13)$ & $0.66(0.08)$ & 0.83 & $0.60(0.04)$ & 0.76 ).07) & 0.63 & $0.48(0.11)$ & 0.63 \\
\hline $\mathrm{Cr}$ & & 1.78 & 2.01 & $2.62(0.34)$ & & 1.99 & $1.34(0.12)$ & $1.68(0.50)$ & 1.57 & & 0.96 \\
\hline $\mathrm{Co}$ & 12.47 & 22.89 & $18.53(4.36)$ & $15.93(2.35)$ & $17.14(3.03)$ & 18.63 & $11.91(3.46)$ & $13.26(3.67)$ & 12.16 & $10.85(1.14)$ & 12.68 \\
\hline$N i$ & & 23.73 & 20.73 & $23.23(2.99)$ & $18.81(1.65)$ & 20.69 & $13.15(3.16)$ & $16.51(3.16)$ & 11.02 & $9.17(1.38)$ & 11.16 \\
\hline $\mathrm{Cu}$ & & 1.92 & 2.82 & $4.98(0.58)$ & $3.08(0.18)$ & 6.07 & 4.05 (1.15) & 3.58 & 3.29 & 3.40 & \\
\hline $\mathrm{Zn}$ & 9.37 & 21.31 & 21.31 & 15.31 & 15.31 & 15.31 & 12.53 & 12.52 & 13.43 & 13.43 & 13.44 \\
\hline$Y$ & & 0.86 & 0.86 & & & & 0.36 & 0.36 & 1.05 & 1.05 & 1.05 \\
\hline $\mathrm{Zr}$ & 0.37 & 0.09 & 0.09 & 0.09 & 0.09 & 0.09 & 0.09 & 0.09 & 0.05 & 0.05 & 0.05 \\
\hline $\mathrm{Nb}$ & $0.84(0.21)$ & 0.34 & $0.33(0.06)$ & $1.04(0.25)$ & $0.90(0.15)$ & 0.87 & $0.21(0.07)$ & $0.25(0.07)$ & 0.97 & 0.82 & \\
\hline$H f$ & 0.15 & 0.48 & & $0.06(0.01)$ & 0.06 & 0.10 & $0.31(0.08)$ & $0.31(0.08)$ & & & \\
\hline $\mathrm{Ta}$ & $1.83(0.41)$ & $0.42(0.21)$ & 0.65 & $2.20(0.58)$ & $1.75(0.39)$ & 1.610 .55 & $0.41(0.16)$ & $0.48(0.18)$ & 1.32 & 1.75 & \\
\hline \multicolumn{12}{|c|}{ Interlayer sites } \\
\hline $\mathrm{Rb}$ & & 2.70 & 2.54 & $2.95(0.28)$ & $2.41(0.07)$ & 2.46 & 2.29 & 1.79 & 2.04 & 1.55 & \\
\hline $\mathrm{Sr}$ & & 0.01 & $0.01(.001)$ & $0.03(.007)$ & $0.03(.008)$ & 0.03 & $0.02(.002)$ & $0.02(.002)$ & 0.04 & $0.02(.005)$ & 0.04 \\
\hline Cs & & 16.60 & 12.47 & $12.35(1.42)$ & $11.41(3.07)$ & 10.05 & 10.31 & $8.50(1.76)$ & 4.39 & 6.06 & \\
\hline $\mathrm{Ba}$ & $0.54(0.10)$ & $0.46(0.06)$ & 0.42 & $0.71(0.08)$ & $0.58(0.11)$ & 0.650 .06 & $0.52(0.07)$ & $0.62(0.11)$ & 0.74 & $0.58(0.05)$ & 0.67 \\
\hline$L a$ & 47.24 & 13.48 & 13.48 & 3.60 & 3.60 & 3.60 & 2.56 & 2.56 & 23.47 & 23.48 & 23.48 \\
\hline $\mathrm{Ce}$ & 27.34 & 4.77 & 4.77 & 5.34 & 5.34 & 5.34 & 8.95 & 8.95 & & & \\
\hline $\mathrm{T}\left({ }^{\circ} \mathrm{C}\right)$ & 622 & 643 & 643 & 658 & 658 & 658 & 656 & 656 & 680 & 680 & 680 \\
\hline $\mathrm{P}$ (kbar) & 9.4 & 9.4 & 9.4 & 8.0 & 8.0 & 8.0 & 8.0 & 8.0 & 12.5 & 12.5 & 12.5 \\
\hline
\end{tabular}

Italicized elements are present in concentrations below or close to 3 times detection limits in either biotite or muscovite. Metamorphic temperatures and pressures were estimated using the garnet-biotite geothermometer of Holdaway et al. (1997), and Grt-Pl-Bt-Ms and Grt-Ky-Qtz-Pl geobarometers of Hodges and Crowley (1985).

ally up to 0.02 atoms p.f.u.). The total occupancy of the interlayer site ranges from 1.80 to 2.02 and is not related to metamorphic grade. Deficiencies in the XII-sites in muscovite, even when trace elements are included in the analyses, may be partially explained by the $\mathrm{H}_{3} \mathrm{OK}_{-1}$ and $\mathrm{NH}_{4} \mathrm{~K}_{-1}$ substitutions and by vacancies in XII-sites due to charge balance constraints caused by other substitutions in IV, VI and XII-sites (Guidotti and Sassi, 1998a; Guidotti and Sassi, 1998b). The analyzed muscovites have less than 0.06 atoms of $\mathrm{F}$ p.f.u. with a strong positive dependence on $\mathrm{Mg}$ content. Most $\mathrm{Cl}$ concentrations are below detection limits.

\section{THERMODYNAMICS OF TRACE ELEMENT DISTRIBUTION}

The partitioning behaviour of trace elements can be considered in terms of exchange reactions involving major element cations for which the thermodynamic basis is well established (e.g., Kretz, 1961). For example, partitioning of the trace element $\mathrm{Cs}$ and the major element $\mathrm{K}$ between coexisting biotite and muscovite may be expressed by the exchange reaction:

$$
\begin{aligned}
& \mathrm{Cs}_{2}^{\mathrm{XII}} \mathrm{Mg}_{6}^{\mathrm{VI}} \mathrm{Al}_{2}^{\mathrm{IV}} \mathrm{Si}_{6}^{\mathrm{IV}} \mathrm{O}_{20}(\mathrm{OH})_{4}+\mathrm{K}_{2}^{\mathrm{XII}} \mathrm{Al}_{4}^{\mathrm{VI}} \mathrm{Al}_{2}^{\mathrm{IV}} \mathrm{Si}_{6}^{\mathrm{IV}} \mathrm{O}_{20}(\mathrm{OH})_{4}= \\
& \mathrm{Cs}-\mathrm{Bt} \quad \mathrm{K}-\mathrm{Ms} \\
& \mathrm{K}_{2}^{\mathrm{XII}} \mathrm{Mg}_{6}^{\mathrm{VI}} \mathrm{Al}_{2}^{\mathrm{IV}} \mathrm{Si}_{6}^{\mathrm{IV}} \mathrm{O}_{20}(\mathrm{OH})_{4}+\mathrm{Cs}_{2}^{\mathrm{XII}} \mathrm{Al}_{4}^{\mathrm{VI}} \mathrm{Al}_{2}^{\mathrm{IV}} \mathrm{Si}_{6}^{\mathrm{IV}} \mathrm{O}_{20}(\mathrm{OH})_{4} \\
& \mathrm{~K}-\mathrm{Bt} \quad \mathrm{Cs}-\mathrm{Ms}
\end{aligned}
$$

At equilibrium,

$$
\mu_{C s-B t}+\mu_{K-M s}=\mu_{K-B t}+\mu_{C s-M s}
$$

where $\mu_{C s-B t}$ is the chemical potential of endmember $C s-B t$, which is related to the concentration by

$$
\mu_{C s-B t}=G_{C s-B t}+R \ln X_{C s-B t} \gamma_{C s-B t}
$$

Here $\mathrm{G}_{C s-B a}$ is the molar Gibbs energy of pure endmember $C s-B t, R$ is the gas constant, $\gamma_{C s-B t}$ is an activity coefficient, and $X_{C s-B t}$ is the mole fraction, $C s /(C s+K)$ in biotite. By introducing three additional equations analogous to Eqn. (3) and substituting them into Eqn. (2), we obtain

$K_{D}^{C s-K}=\left[\frac{X_{C s}}{X_{K}}\right]^{B t} /\left[\frac{X_{C s}}{X_{K}}\right]^{M s}=\left[\frac{\gamma_{K}}{\gamma_{C s}}\right]^{B t}\left[\frac{\gamma_{C s}}{\gamma_{K}}\right]^{M s}\left\{\exp \left(\frac{-\Delta G^{\circ}}{R T}\right)\right\}$

where $K_{D}^{C s-K}$ is the distribution coefficient for $C s$ in K-biotite/ $\mathrm{K}$-muscovite, and $\Delta \mathrm{G}^{\circ}$ is the Gibbs energy difference in reaction (1) with all components pure. In dilute solutions, the activity coefficients are expected to remain constant following Henry's Law. Therefore, the concentration ratio will also remain constant by the Gibbs-Duhem equation. $\Delta G^{\circ}$ is thus mainly dependent on variations in $\mathrm{T}$. The effects of $\mathrm{P}$ are predicted to be small owing to very small changes in the volume of reaction as a result of the exchange reactions. Because $X_{K-B t}$ and $X_{K-M s}$ are very nearly 1.0 , the distribution coefficient on the left may be written $X_{C s-B t} / X_{C s-M s}$. Hence, for a very low concentration of $C s$, we would expect a linear relation between $X_{C s-B t}$ and $X_{C s-M s}$ at constant temperature.

\section{THE DISTRIBUTION OF TRACE ELEMENTS}

The abundance ranges and partitioning behaviour of the trace elements among the 22 biotite-muscovite pairs are presented in 
Table 8. Comparison of the Nernst distribution coefficients $\left(\mathrm{D}_{\mathrm{i}}\right)$ between biotite and muscovite with those of previous studies.

\begin{tabular}{|c|c|c|c|c|c|c|c|}
\hline \multirow[b]{2}{*}{ Facies } & \multicolumn{2}{|c|}{ This study } & \multirow{2}{*}{$\begin{array}{c}\begin{array}{c}\text { Dahl et al. } \\
(1993)\end{array} \\
\text { Amphibolite }\end{array}$} & \multirow{2}{*}{$\begin{array}{l}\begin{array}{c}\text { Domanik et al. } \\
(1993)\end{array} \\
\text { Ep. Blueschist }\end{array}$} & \multirow{2}{*}{$\begin{array}{l}\text { Dutrow et al. } \\
\frac{(1986)}{\text { Amphibolite }}\end{array}$} & \multirow{2}{*}{$\begin{array}{c}\begin{array}{c}\text { Butler } \\
(1967)\end{array} \\
\text { U. Greenschist }\end{array}$} & \multirow{2}{*}{$\begin{array}{c}\begin{array}{c}\text { Moorbath et al. } \\
(1968)\end{array} \\
\text { Amphibolite } \\
\end{array}$} \\
\hline & U. Greenschist & Amphibolite & & & & & \\
\hline Methods & \multicolumn{2}{|c|}{ LAM-ICP-MS } & Solution ICP-MS & SIMS & AA & Spectrography & Isotope Dilution \\
\hline \multicolumn{8}{|c|}{ Octahedral sites } \\
\hline $\mathrm{Mn}$ & $20.62(5.73)$ & $24.18(9.64)$ & $16.96(7.22)$ & & & & \\
\hline $\mathrm{Li}$ & $2.38(1.22)$ & $4.49(0.56)$ & $5.31(1.47)$ & & $4.57(0.68)$ & & \\
\hline $\mathrm{Sc}$ & $0.31(0.04)$ & $0.77(0.24)$ & $0.49(0.12)$ & & & & \\
\hline V & $0.50(0.06)$ & $0.86(0.18)$ & $0.88(0.15)$ & & & & \\
\hline $\mathrm{Cr}$ & $0.95(0.34)$ & $2.35(0.67)$ & $1.30(0.32)$ & & & & \\
\hline Co & $13.04(2.51)$ & $20.41(5.05)$ & $3.45(2.15)$ & & & & \\
\hline $\mathrm{Ni}$ & $12.15(3.71)$ & $22.68(7.30)$ & $18.03(7.93)$ & & & & \\
\hline $\mathrm{Cu}$ & $2.18(0.79)$ & $4.98(1.68)$ & $2.52(1.53)$ & & & & \\
\hline $\mathrm{Zn}$ & $12.73(2.11)$ & $20.00(4.76)$ & $17.77(10.43)$ & & & & \\
\hline Y & $1.02(0.57)$ & $1.07(0.41)$ & $1.94(2.15)$ & & & & \\
\hline $\mathrm{Zr}$ & $0.58(0.19)$ & $0.15(0.12)$ & $0.74(0.25)$ & & & & \\
\hline $\mathrm{Nb}$ & $1.67(0.22)$ & $0.89(0.45)$ & & & & & \\
\hline $\mathrm{Hf}$ & $0.55(0.34)$ & $0.28(0.21)$ & & & & & \\
\hline Та & $3.43(0.72)$ & $1.68(0.93)$ & & & & & \\
\hline \multicolumn{8}{|c|}{ Interlayer sites } \\
\hline $\mathrm{Na}$ & $0.47(0.11)$ & $0.28(0.03)$ & $0.21(0.11)$ & & & & \\
\hline $\mathrm{Rb}$ & $1.80(0.25)$ & $2.07(0.40)$ & & 2.08 & & $1.85(0.78)$ & 1.52 \\
\hline $\mathrm{Sr}$ & $0.01(0.00)$ & $0.02(0.01)$ & $0.32(0.33)$ & 0.03 & & & 0.40 \\
\hline Cs & $14.81(5.64)$ & $9.21(3.26)$ & & & & & \\
\hline $\mathrm{Ba}$ & $0.23(0.04)$ & $0.53(0.09)$ & $0.44(0.34)$ & 0.57 & & $0.42(0.05)$ & \\
\hline $\mathrm{La}$ & $8.48(6.12)$ & $13.11(12.70)$ & $0.72(0.55)$ & & & & \\
\hline $\mathrm{Ce}$ & $2.76(1.10)$ & $8.03(7.04)$ & & & & & \\
\hline $\mathrm{Ca}$ & $0.37(0.09)$ & $0.65(0.19)$ & $2.07(1.09)$ & & & $0.48(0.08)$ & \\
\hline
\end{tabular}

The data of Dahl et al. (1993) represent an average of the St- and Sil-zones. Values in parentheses represent standard deviations at $1 \sigma$ level. Abbreviations: SIMS; secondary ion mass spectrometry, AA: atomic absorption spectrophotometry.

Figure $2(\mathrm{a}-\mathrm{u})$. Also included for comparison in these plots are data from Dahl et al. (1993) who reported ICP solution analyses of separates from 49 coexisting biotite-muscovite pairs from the staurolite and sillimanite zones in the Black Hills of South Dakota. The partition coefficients are presented here both as ppm concentration ratios

$$
D_{i}=\frac{p p m B t}{p p m M s}
$$

equivalent to Nernst distribution coefficients, and as atomic or molar partition coefficients

$$
D_{i}^{*}=\frac{X_{i}^{B t}}{X_{i}^{M s}}
$$

following the terminology of Beattie et al. (1993). In these relationships, $i$ refers to a specific element and $\mathrm{X}_{i}$ is the mole fraction of component $i$ in biotite or muscovite on a specific site, calculated on the basis of two interlayer sites, eight tetrahedral sites, and either six or four octahedral sites for biotite and muscovite, respectively. $\mathrm{D}_{i}^{*}$ values between coexisting biotite and muscovite determined in this study are listed in Table 7 , with their corresponding standard deviations $(1 \sigma)$. Metamorphic P-T were estimated using garnet-plagioclase-biotite-muscovite and garnet-kyanite-quartz-plagioclase geobarometers of Hodges and Crowley (1985) and garnet-biotite geothermometry of Holdaway et al. (1997) (Table 7). Garnet-biotite geo- thermometers incorporating significant corrections for calcium in garnet, such as those of Hoinkes (1986), Williams and Grambling (1990) and the TWQ program, version 2.02 (Berman, 1991) invariably yield unreasonably high temperatures for low-T samples which contain garnet enriched in calcium $(\sim 0.2$ mole fraction) compared to high- $\mathrm{T}$ garnets $(<0.1$ mole fraction). There is a temperature gap between low- and high-T samples, which may correspond to the missing staurolite-biotite zone noted above. As discussed above, distribution coefficients of $\mathrm{Ni}, \mathrm{Cu}, \mathrm{Y}, \mathrm{Zr}, \mathrm{La}, \mathrm{Ce}$ and $\mathrm{Hf}$ involve relatively high analytical errors because of their concentrations in either biotite or muscovite or both approach detection limits. The distribution coefficients for these elements, therefore, should be considered as only rough estimates.

\subsection{Trace Element Distribution}

For the trace elements, it is evident from Figure 2 that:

1. Li, Mn, Co, Ni, Cu, Zn, Rb, Nb, Cs, La, Ce and Ta prefer biotite over muscovite regardless of metamorphic grade;

2. At low-T, $\mathrm{Cr}$ and $\mathrm{Y}$ partition coefficients are nearly equal between the micas; and

3. Sc, V, Cr (high-T), Sr, Zr, Ba and Hf favour muscovite.

The distributions of $\mathrm{Li}, \mathrm{Sc}, \mathrm{V}, \mathrm{Cr}, \mathrm{Nb}$ and $\mathrm{Ba}$ show systematic differences between low- and high-T micas (Figs. 2a,b,d,e,o,q). The factors governing these differences are discussed in a later 


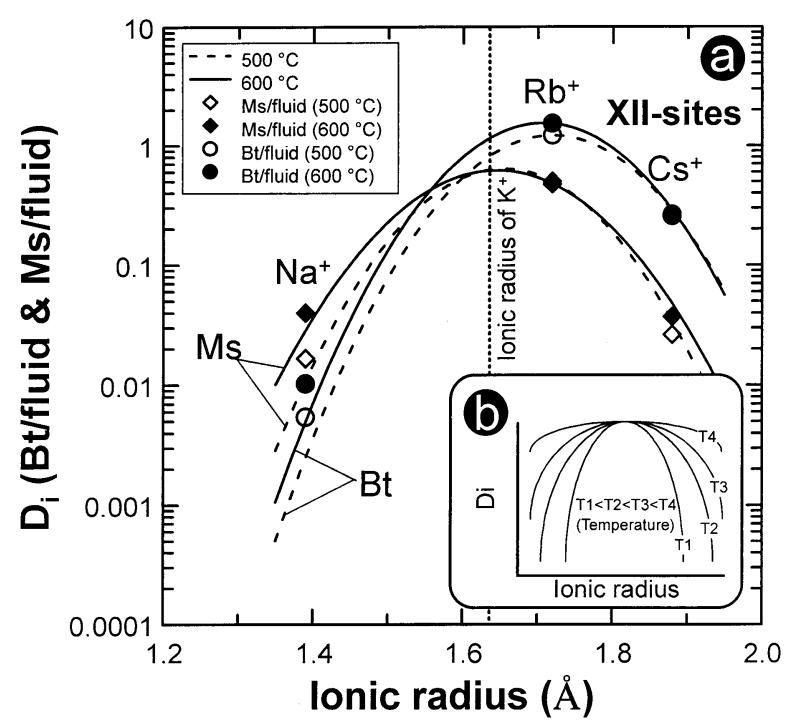

Fig. 3. (a) Crystal-fluid partition coefficient vs. ionic radius for interlayer cations in phlogopite and muscovite. Data are from Volfinger (1976). Curves are calculated from Eqn. (5). Dotted line indicates ionic radius of $\mathrm{K}^{+}$. (b) Schematic diagram showing the predicted decrease of slopes with increasing temperature.

section. The decreasing concentrations of $\mathrm{Sc}, \mathrm{Mn}$ and $\mathrm{Y}$ in micas with metamorphic grade (Figs. 2b,f,m) indicate that the matrix is progressively depleted in these elements, probably because of the increasing modal abundance of garnet, which is known to strongly sequester them. The distribution of Ti between biotite and muscovite is strongly controlled by $X_{M g}$ of muscovite (not shown).

As indicated by the thermodynamic considerations above, the systematic linear distributions of most trace elements at similar metamorphic grade, together with the measured distributions intersecting at the origin (Fig. 2), suggest a close approach to chemical equilibrium between coexisting biotite and muscovite across the range of bulk-rock composition and metamorphic grade. In addition, there is no evidence that any of the trace elements departs from Henry's Law behaviour.

However, it is noteworthy that biotite and muscovite from sample 87-279 show variations in Sc ranging from 14 to 22 and from 55 to $74 \mathrm{ppm}$, respectively, but with similar distribution coefficients (Fig. 2b). Analytical errors can be ruled out, because they are especially low for Sc due to its abundance well above the detection limits in both biotite and muscovite, and the absence of spectral interferences. The variability in Sc concentrations at the thin-section scale may be attributed to mosaic equilibrium (initially defined by Zen, 1963), which is caused by limited diffusion ranges of the element under the metamorphic conditions. Kretz et al. (1999) also reported evidence for different domains of equilibrium for specific trace elements, which they attributed to variations in the magnitudes of deformation and recrystallization, together with different diffusion rates.

\subsection{Contamination}

Most trace elements in the micas show similar abundance ranges when compared to the data of Dahl et al. (1993), but Zr,
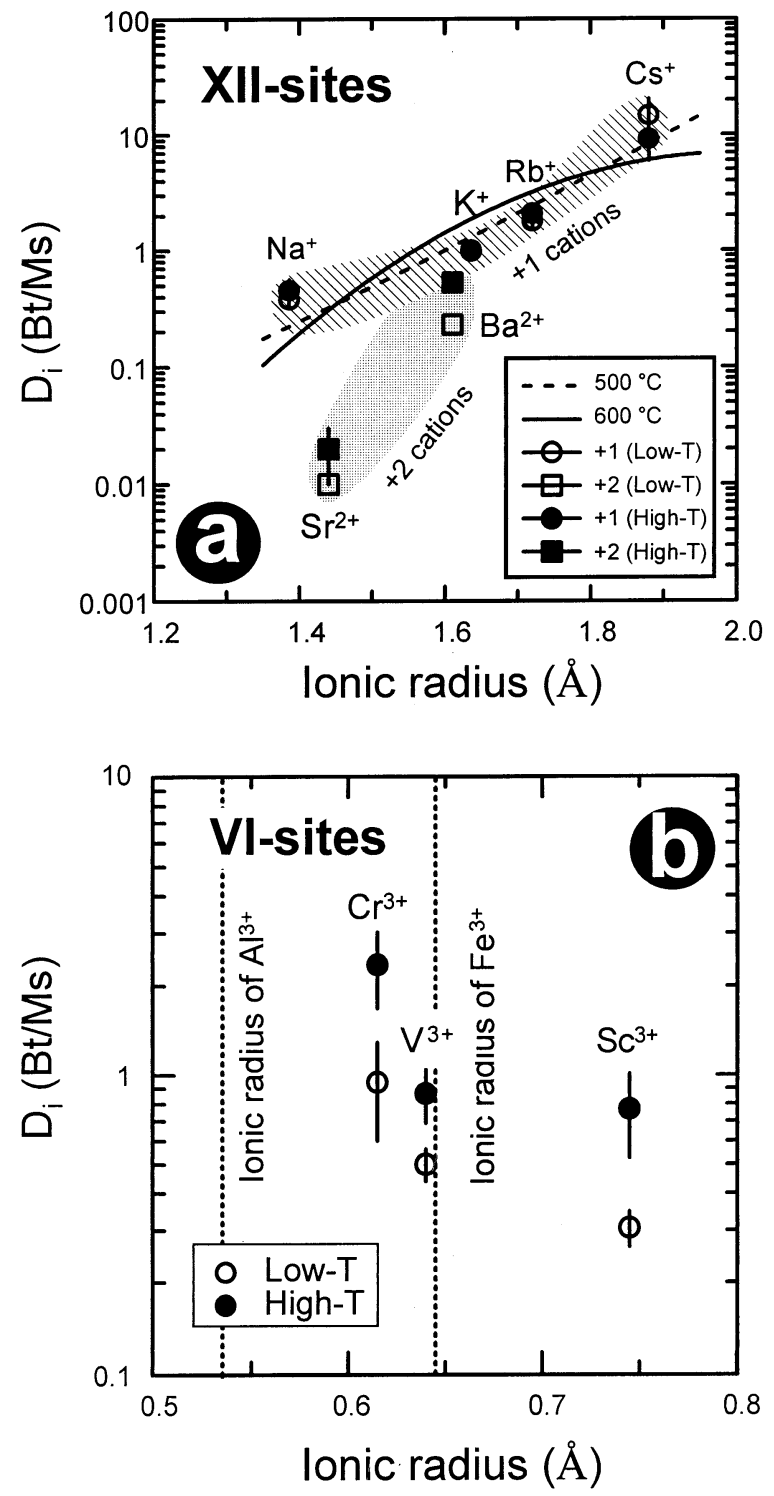

Fig. 4. Relationship between distribution coefficient and ionic radius. (a) $\mathrm{D}_{\mathrm{i}}$ values for low and high-T micas plotted against ionic radius for monovalent and divalent cations in XII-interlayer sites (shaded areas), along with distribution lines for 500 and $600{ }^{\circ} \mathrm{C}$ (solid and dashed lines) calculated from the data of Volfinger (1976). (b) $\mathrm{D}_{\mathrm{i}}$ values of $3+$ cations in VI-sites plotted against corresponding ionic radius. For reference, ionic radii of $\mathrm{Al}^{3+}$ and $\mathrm{Fe}^{3+}$ ions are shown.

La and Ce are much lower in our analyses (Fig. 2n,r,s). This result is clearly due to contamination from zircons and monazite in their samples, which are difficult to remove from mineral separates. Moreover, consistently lower contents of $\mathrm{Mn}$ and Co in muscovite and higher $\mathrm{Ca}$ and $\mathrm{Sr}$ contents in biotite from our data (Figs. 2f,g,l; Table 3) indicate that there may have been other important sources of contamination in Dahl et al.'s data. High Mn and Co in muscovite analyses of Dahl et al. (1993) may be attributed to contamination by ilmenite, despite their efforts to remove it using a high strength magnetic field. They reported that $\mathrm{Sr}$ data of their muscovite were contaminated by oligoclase and applied corrections using $\mathrm{Sr}$ contents in oligo- 

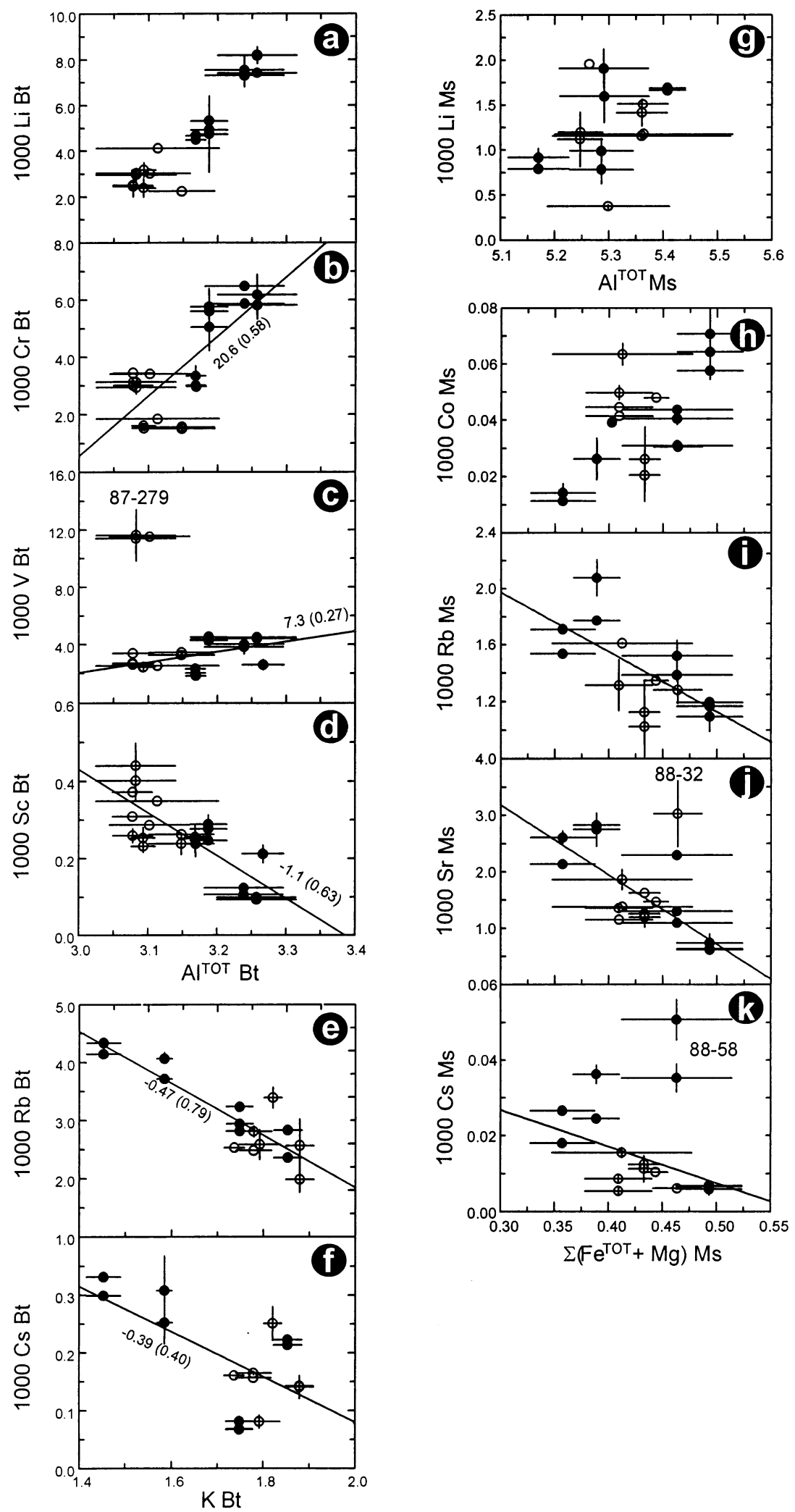

Fig. 5. (a-d) The concentrations of $\mathrm{Li}, \mathrm{Cr}, \mathrm{V}$ and $\mathrm{Sc}$ versus $\mathrm{Al}^{\mathrm{TOT}}$ in biotite. Note that the effects of $\mathrm{Al}^{\mathrm{TOT}}$ on the contents of $\mathrm{Cr}, \mathrm{V}$ and $\mathrm{Sc}$ are different. (e-f) The concentrations of $\mathrm{Rb}$ and $\mathrm{Cs}$ in biotite versus $\mathrm{K}$ contents. $(\mathrm{g}$ ) $\mathrm{Li}$ in muscovite versus $\mathrm{Al}^{\mathrm{TOT}}$. (h-k) $\mathrm{Co}, \mathrm{Rb}, \mathrm{Sr}$ and $\mathrm{Cs}$ versus $\Sigma\left(\mathrm{Fe}^{\mathrm{TOT}}+\mathrm{Mg}\right)$ of muscovite. Open and closed circles represent low and high-T samples, respectively. Regression lines are shown, and the numbers represents slope of regression lines, with $\mathrm{r}^{2}$ in parentheses, where these are significant. 
clase. However, significantly higher $\mathrm{Sr}$ contents in biotite, together with high $\mathrm{Ca}$ contents in the biotites of Dahl et al. (1993), indicate that their biotite analyses were also probably contaminated by oligoclase (Fig. 2l). Bea et al. (1993) reported a similar difference between LAM-ICP-MS and mineral separate analyses for biotite. Their solution ICP-MS analyses for REE, Th, U, Y, Sr, Zr, Cu and Zn were consistently higher, by almost two orders of magnitude, than results from analyzing the same crystals in thin section with a LAM-ICP-MS.

\subsection{Comparison}

The measured distribution coefficients from this study are compared with other data from pelitic rocks, most of which represent amphibolite facies conditions, except for those of Butler (1967) which are for greenschist facies conditions (Table 8). In Table 8, the data of Dahl et al. (1993) and Butler (1967) are averages of their staurolite and sillimanite-zones samples, and samples with no epidote, respectively. Overall, the trace element distributions and relative enrichment patterns are consistent with published analyses of coexisting biotite and muscovite (e.g., Butler, 1967; Moorbath et al., 1968; Dutrow et al., 1986; Hervig and Peacock, 1989; Dahl et al., 1993; Domanik et al., 1993). However, there are important differences between this and previous studies.

The average $\mathrm{D}_{\mathrm{Li}}, \mathrm{D}_{\mathrm{V}}$ and $\mathrm{D}_{\mathrm{Ba}}$ values of high-T samples show good agreement with those of Dahl et al. (1993) (Table 8). The average $D_{L i}$ value of high-T samples also shows excellent agreement with that of Dutrow et al. (1986). The measured $\mathrm{D}_{\mathrm{Ba}}$ value from high-T samples is similar to values reported for epidote-bearing blueschists from the Franciscan Complex by Domanik et al. (1993) within permitted errors, implying no significant pressure or bulk composition dependence on Ba distribution (Table 8). However, the $\mathrm{D}_{\mathrm{Ba}}$ value of Butler (1967), which was obtained from an upper greenschist facies pelite, is higher than that of our low-T samples (Table 8). Distribution coefficients of $\mathrm{Li}, \mathrm{V}$ and $\mathrm{Ba}$ between biotite and muscovite increase with metamorphic grade (Table 8).

For Sc and Cr, the distribution coefficients of Dahl et al. (1993), which are from a metamorphic grade equivalent to our high-T samples, are close to our low-T samples (Table 8). A close examination of the plots for Sc and Cr from Dahl et al. (1993) reveals that their staurolite-zone data are close to our high-T data, but their sillimanite zone data overlap with the low-T data from this study (Fig. 2b, e). In addition, on the basis of the observed trend for $\mathrm{V}$ partitioning between biotite and muscovite in this study, the partitioning of $\mathrm{Sc}$ and $\mathrm{Cr}$ are expected to increase with T. However, the opposite trends in the data of Dahl et al. (1993) may indicate that their Sc and Cr compositions from the sillimanite-zone micas were re-equilibrated at lower temperatures, or that their data were influenced by an increasing amount of secondary (retrograde) micas in the sillimanite-zone.

Our distribution coefficients for $\mathrm{Ca}$, $\mathrm{Co}$ and $\mathrm{Sr}$ differ significantly from those Dahl et al. (1993), probably because of contamination in either biotite or muscovite in their analyses as mentioned above. In support of this assertion, $\mathrm{D}_{\mathrm{Sr}}$ of Domanik et al. (1993), which was determined by the SIMS technique, shows a good agreement with our high-T results (Table 8). On the other hand, $\mathrm{D}_{\mathrm{Sr}}$ values determined by a bulk mineral anal- ysis method such as employed by Dahl et al. (1993) and Moorbath et al. (1968) are 10 times higher.

Partitioning of $\mathrm{Rb}$ between biotite and muscovite is within the range of values reported in the literature and shows little variation through the entire range of bulk composition and metamorphic grade. $\mathrm{Mn}, \mathrm{Ni}, \mathrm{Cu}$ and $\mathrm{Zn}$ data from $\mathrm{Dahl}$ et al. (1993) plot on or very close to our trends (Fig. 2). For the distribution of $\mathrm{Nb}, \mathrm{Hf}$, Ta and $\mathrm{Cs}$ between coexisting micas, no published data from pelitic micas are available for comparison.

The comparison of data given above enables us to conclude that our partition coefficients are more reliable than the results from several previous studies which were obtained by means of bulk analysis of mineral separates. Assuming an equilibrium distribution of trace elements, as is suggested by our data, we now discuss the distribution behaviour of trace elements in terms of various structural, compositional or thermal controls on element partitioning.

\section{FACTORS INFLUENCING THE DISTRIBUTION COEFFICIENTS}

\subsection{Crystal Structural Effects}

Crystal-melt partitioning behaviour of trace elements for various minerals has been modeled in terms of the lattice strain associated with placing a cation on a particular crystallographic site when the radius of the cation differs from the optimal radius for that site (e.g., Onuma et al. 1968; Möller 1988; Blundy and Wood, 1991, 1994; Beattie, 1994; Brenan et al., 1995). Trace element partitioning in mica-melt and mica-fluid systems also shows that the incorporation of a trace element into the crystal lattice is controlled by the size mismatch between the trace and host cations in the mica structures (Jensen, 1973; Matsui et al., 1977; Iiyama, 1979; Volfinger and Robert, 1980; LaTourrette et al., 1995). Using the phlogopitefluid and muscovite-fluid partition coefficients experimentally measured by Volfinger (1976) at 500 and $600^{\circ} \mathrm{C}$ at a constant pressure of $1 \mathrm{kbar}$, we test the model in order to develop analogous relations that describe biotite/muscovite partition coefficients in terms of the ionic radius of the substituting trace elements.

We assume, for example for reaction (1), that $\Delta \mathrm{G}_{\text {exchange }}$ can be approximated by the energy required to remove a $\mathrm{Cs}^{+}$ion from the biotite and insert it into the crystal lattice of muscovite while simultaneously transferring a $\mathrm{K}^{+}$ion from muscovite to biotite. The structural work required to incorporate a $\mathrm{Cs}^{+}$into the muscovite is the sum of $\Delta \mathrm{G}_{\text {strain }}$, the lattice strain due to size mismatch between the radius of $\mathrm{Cs}^{+}$and the optimum radius $\left(\mathrm{r}_{\mathrm{o}}\right)$ of the XII-site in muscovite, and $\Delta_{\text {relaxation, }}$, the energy liberated when a $\mathrm{Cs}^{+}$ion is removed from the lattice site in biotite, assuming major element substitution contributes a negligible amount of $\Delta \mathrm{G}_{\text {strain }}$ and $\Delta \mathrm{G}_{\text {relaxation }}$ because of its similarity in ionic radius to the optimum size of the crystallographic site.

Following the method of Blundy and Wood (1994), we have fitted the partitioning data of Volfinger (1976) by non-linear least-squares regression to the relation:

$$
\begin{aligned}
& D(P, T, X)=D_{o}(P, T, X) \\
& \cdot \exp \left[\frac{-4 \pi E N_{A}}{R T}\left\{\frac{r_{o}}{2}\left(r_{i}-r_{o}\right)^{2}+\frac{1}{3}\left(r_{i}-r_{o}\right)^{3}\right\}\right]
\end{aligned}
$$



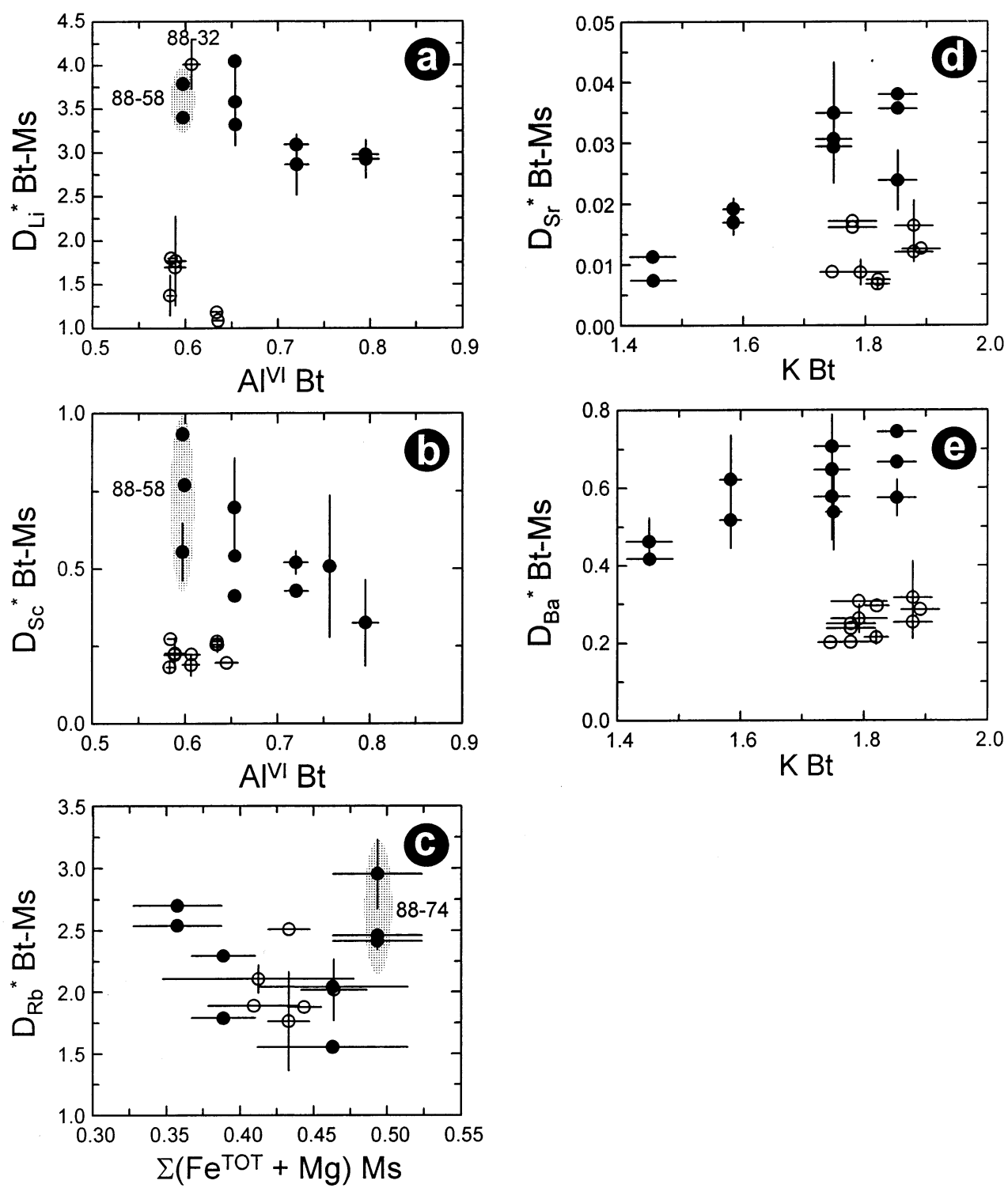

Fig. 6. (a-e) Major element compositional effects of $\mathrm{Al}^{\mathrm{VI}}, \mathrm{\Sigma}\left(\mathrm{Fe}^{\mathrm{TOT}}+\mathrm{Mg}\right)$ and $\mathrm{K}$ of either biotite or muscovite on the distribution of $\mathrm{Li}, \mathrm{Sc}, \mathrm{Rb}, \mathrm{Sr}$ and $\mathrm{Ba}$ between biotite and muscovite. All of the trace elements except for $\mathrm{Rb}$ show two different trends with metamorphic grade. Open and closed circles represent low and high-T, respectively.

which relates the partition coefficient, $D(P, T, X)$, for a given cation of ionic radius $\mathrm{r}_{\mathrm{i}}$, at a particular condition of $P, T$ and bulk composition, to the partition coefficient, $D_{o}(P, T, X)$, for a cation whose radius equals the optimal site radius, $\mathrm{r}_{\mathrm{o}}$. In this relation, $\mathrm{E}$ is the value of Young's modulus for the site, $N_{A}$ is Avogadro's number, $R$ is the gas constant and $T$ is in Kelvins. The data and associated fits using Eqn. (7) are shown in Figure 3 in which the slope of the parabola is a function of E. Partition coefficients for elements substituting into XII-sites in biotite and muscovite decrease as the cation size misfit increases, consistent with incorporation of the trace element becoming less favourable with increasing lattice strain. Variations in $D_{i}^{M s-\text { fluid }}$ with $\mathrm{T}$ are greater for $\mathrm{Na}$ and $\mathrm{Cs}$ than for $\mathrm{Rb}$ (Fig. 3a), consistent with the ionic radius of $\mathrm{Rb}$ being close to the ideal radius for the site (Fig. $3 \mathrm{~b}$ ). For $D_{i}^{B t-\text { fluid }}$, in contrast, the pattern is different, with Cs partitioning showing the least effect of $\mathrm{T}$. This is not in accord with expections, since the ionic radius of $\mathrm{Rb}$ is close to the ideal radius for the site, suggesting that it should show the least variation with T. Although we are unable to unambiguously explain this result, we suspect that it may be due to poor quality analytical data for Cs for the biotite experiments.

It is noteworthy that the derived peak value for $r_{o}$ for $1+$ cations in biotite is slightly larger than that for muscovite. In biotite, the peak $r_{o}$ coincides with the radius of $\mathrm{Rb}^{+}$ion. In contrast, in muscovite the peak closely corresponds to the radius of the $\mathrm{K}^{+}$ion. This difference in optimum ionic radius of XII-sites between biotite and muscovite is compatible with the fact that ideal trioctahedral biotite has a completely filled octahedral sheet (filled by the relatively large $\mathrm{Fe}^{2+}$ and $\mathrm{Mg}^{2+}$ 

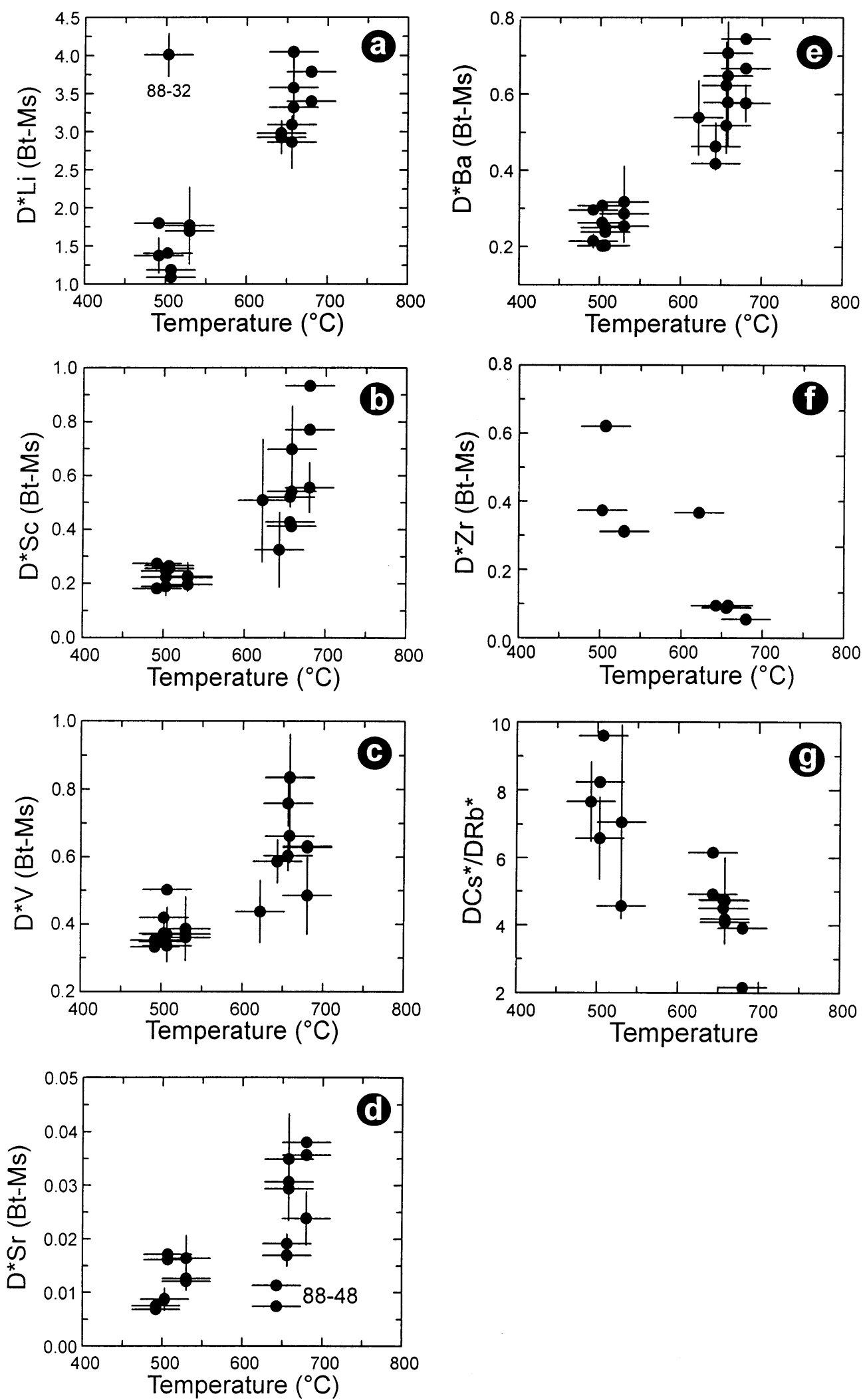

Fig. 7. (a-g) Plots of $D_{\mathrm{Li}}^{*}, D_{\mathrm{Sc}}^{*}, D_{\mathrm{V}}^{*}, D_{\mathrm{Sr}}^{*}, D_{\mathrm{Cs}}^{*}, D_{\mathrm{Ba}}^{*}, D_{\mathrm{Zr}}^{*}$ and $D_{\mathrm{Cs}}^{*} / \mathrm{D}_{\mathrm{Rb}}^{*}$ against metamorphic temperatures estimated using the garnet-biotite geothermometer. 
cations), whereas ideal muscovite has smaller and fewer octahedral sites as a result of the tetrahedral rotation necessary to accommodate the size mismatch between the IV and VI-sheets (Guidotti and Sassi, 1998b). The decreasing slopes of the curve for +1 cations in XII-sites of muscovite, as the temperature increases from 500 to $600^{\circ} \mathrm{C}$, may indicate variations in thermal expansivity with $\mathrm{T}$ (Fig. 3). If this is true, we would expect more significant thermal effects for elements away from the optimum ionic radius. The slopes of parabolas for XII-sites in biotite do not appear to change with $\mathrm{T}$.

On the basis of biotite-fluid and muscovite-fluid partitioning, the distributions of trace elements between coexisting biotite and muscovite would be expected to vary systematically with ionic radius, if lattice strain were a major controlling factor. Fig. 4a shows the curve for $D_{i}^{B t-m s}$, derived by dividing the values for $D_{i}^{B t-\text { fluid }}$ by those for $D_{i}^{\text {ms-fluid }}$ in Fig. 3, together with our data. Overall, our partitioning data for $\mathrm{Na}, \mathrm{K}, \mathrm{Rb}$ and $\mathrm{Cs}$ fit the modeled biotite-muscovite partitioning curves very well, demonstrating controls of ionic radius on solid-solid partitioning. It is evident from Fig. 4a that cations $\mathrm{Ba}^{2+}(1.61$ $\AA), \mathrm{Sr}^{2+}(1.44 \AA)$ and $\mathrm{Na}^{+}(1.39 \AA)$ favour muscovite with its smaller interlayer site, whereas $\mathrm{K}^{+}(1.64 \AA)$ is equally partitioned between biotite and muscovite. In contrast, $\mathrm{Rb}^{+}(1.72$ $\AA$ ) and $\mathrm{Cs}^{+}(1.88 \AA)$ which are larger than $\mathrm{K}^{+}$, favour the more open structure of biotite. In octahedral sites, distribution coefficients exhibit the sequence $\mathrm{Cr}^{3+}(0.615 \AA)>\mathrm{V}^{3+}(0.64 \AA)>$ $\mathrm{Sc}^{3+}(0.745 \AA)$ for $3+$ cations, implying that biotite has the smaller optimum ionic radius for $3+$ cations in octahedral sites (Fig. 4b). This is consistent with the smaller mean octahedral metal-oxygen bond length of the M1-M2 site of $1 \mathrm{M}$ biotite ( $2.093 \pm 0.027 \AA$ ) compared to the M2 site of $2 \mathrm{M} 1$ muscovite (2.236 $\pm 0.021 \AA$ ) (Bailey, 1984). We can also infer that octahedral $\mathrm{Fe}^{3+}$ is probably slightly favoured in muscovite over biotite on the basis of the ionic radius argument (Fig. 4). For the distribution of divalent transition elements in the VIsites, it is difficult to evaluate the effects of ionic radius or crystal-field stabilization energy because of the high analytical errors involved in the determination of distribution coefficients for $\mathrm{Ni}, \mathrm{Cu}$ and $\mathrm{Zn}$.

\subsection{Compositional Effects}

$\mathrm{Li}^{+}$contents of biotite correlate positively with $\Sigma\left(\mathrm{Al}^{\mathrm{IV}}+\mathrm{Al}^{\mathrm{VI}}\right)$ contents of biotite (Fig. 5a). There is a similar, but less evident, relationship between $\mathrm{Li}^{+}$and $\Sigma\left(\mathrm{Al}^{\mathrm{IV}}+\mathrm{Al}^{\mathrm{VI}}\right)$ of muscovite (Fig. $5 \mathrm{~g}$ ). The Li contents of biotite and muscovite also show weak negative correlations with $\Sigma\left(\mathrm{Fe}^{\mathrm{TOT}}+\mathrm{Mg}\right)$ contents (not shown), indicating that the main atomic substitution in the micas is $\mathrm{Li}_{3} \mathrm{Al}_{-1} \square_{-2}$ in octahedral sites with $\mathrm{Li}_{2}(\mathrm{Fe}, \mathrm{Mg})_{-1} \square_{-1}$ being subordinate. The incorporation of $\mathrm{Cr}$, $\mathrm{V}$, and $\mathrm{Sc}$ into biotite is controlled by the content of $\mathrm{Al}^{\mathrm{TOT}}$, with the slope and its sign depending on ionic radius (Fig. $5 \mathrm{~b}, \mathrm{c}, \mathrm{d})$. Cr shows a stronger positive correlation with $\mathrm{Al}^{\mathrm{TOT}}$ of biotite, than V. On the other hand, Sc shows a negative correlation with $\mathrm{Al}^{\mathrm{TOT}}$, indicating that the presence of $\mathrm{Al}$ does not promote the incorporation of Sc into the biotite structure. Such correlations, however, are not observed in coexisting muscovite, because of the relatively small variations of $\mathrm{Al}^{\mathrm{TOT}}$. The concentrations of $\mathrm{Rb}^{+}$and $\mathrm{Cs}^{+}$in biotite show negative correlations with $\mathrm{K}^{+}$, suggesting that the incorporation of the smaller $\mathrm{K}^{+}$cations reduces the optimum ionic radius of the interlayer sites (Figs. 5e,f). A positive correlation between the Co content and $\Sigma\left(\mathrm{Fe}^{\mathrm{TOT}}+\mathrm{Mg}\right)$ in muscovite (Fig. 5h) indicates that Co incorporation is facilitated by higher contents of the larger $\mathrm{Fe}^{2+}$ and $\mathrm{Mg}^{2+}$ cations replacing $\mathrm{Al}^{\mathrm{VI}}$. Increased amounts of phengite components in muscovite are expected to produce a larger XII-site, due to a smaller tetrahedral rotation angle $(\alpha)$ being required for articulation of the IV and VI-sheets (Harlow, 1995; Guidotti and Sassi, 1998b). Indeed, Volfinger (1974) found that Mg in VI-sites correlated positively with the replacement of $\mathrm{K}^{+}$by $\mathrm{Rb}^{+}$and $\mathrm{Cs}^{+}$. However, $\mathrm{Rb}, \mathrm{Sr}$, and $\mathrm{Cs}$ contents of our muscovites show negative correlations with $\Sigma\left(\mathrm{Fe}^{\mathrm{TOT}}+\mathrm{Mg}\right)$, which more likely controls the substitution of these elements rather than $\mathrm{Mg}^{2+}$ alone. Thus, the relationships between $\Sigma\left(\mathrm{Fe}^{\mathrm{TOT}}+\mathrm{Mg}\right)$ and the contents of $\mathrm{Rb}, \mathrm{Sr}$, and $\mathrm{Cs}$ in muscovite cannot be attributed to the expansion of interlayer sites by the phengite substitution in muscovite. Instead, it may reflect pressure dependence, because $\Sigma\left(\mathrm{Fe}^{\mathrm{TOT}}+\mathrm{Mg}\right)$ in muscovite increases strongly as a function of pressure (Guidotti and Sassi, 1998b). Substitution of $\mathrm{Sr}^{2+}$ and $\mathrm{Ba}^{2+}$ into XII-sites of micas must involve a coupled substitution or vacancies to maintain charge balance, but our data do not allow us to identify the mechanism.

Compositional effects on trace element partitioning are evident if solid solution is not ideal and there are interactions between the constituent molecules, so that the excess chemical potentials of these molecules contribute to the equilibrium constant in Eqn. (4). In examining compositional dependence, molar proportions, rather than weight proportions, are used. In general, biotite favours divalent transition elements in VI-sites due to the higher abundance of appropriately sized sites compared to coexisting muscovite (Dahl et al., 1993). Based on the same argument, strong affinities of $\mathrm{V}^{3+}$ and $\mathrm{Sc}^{3+}$ for muscovite can be explained by appropriate sites for these elements in muscovite.

$\mathrm{D}_{\mathrm{Li}}^{*}$ and $\mathrm{D}_{\mathrm{Sc}}^{*}$ show negative dependence on $\mathrm{Al}^{\mathrm{VI}}$ contents of biotite with two different trends depending on metamorphic grade (Figs. 6a,b). The possibility of an effect due to the difference in Al-saturation level between the two groups can be ruled out because sample 88-58, which is the only Al-undersaturated sample from high-T group, shows the same trend as other high-T samples with respect to the distribution of $\mathrm{Li}$ and Sc. The reason for the high distribution coefficient of $\mathrm{Li}$ in sample 88-32, which belongs to low-T group, is not known. Figure $6 \mathrm{c}$ shows that the distribution of $\mathrm{Rb}$ between biotite and muscovite is governed by the $\Sigma\left(\mathrm{Fe}^{\mathrm{TOT}}+\mathrm{Mg}^{2+}\right)$ content of muscovite. $\mathrm{Sr}$ and $\mathrm{Ba}$ distributions between biotite and muscovite are strongly controlled both by metamorphic grade and the $\mathrm{K}$ contents of biotite (Fig. 6d,e). Figure 6 also shows that the distributions of $\mathrm{Li}, \mathrm{Sc}, \mathrm{Sr}$ and $\mathrm{Ba}$ are dependent both on major element composition and metamorphic temperature, making the separation of the two competing factors difficult.

\subsection{Temperature Effects}

The equilibrium constant $K_{D}$ in Eqn. (4) should vary with $T$ according to the relation

$$
L n K_{D}=-\frac{\Delta H^{o}}{R T}+\frac{\Delta S^{o}}{R}
$$


if the constant $K_{D}$ is solely determined by $\Delta G_{\text {exchange }}^{\circ}$ of a reaction such as (1). To evaluate thermal effects, $D_{i}^{*}$ values for $\mathrm{Li}, \mathrm{Sc}, \mathrm{V}, \mathrm{Sr}, \mathrm{Ba}$ and $\mathrm{Zr}$ are plotted against metamorphic temperature estimated using the garnet-biotite geothermometer (Fig. 7 a-f). Positive correlations between $\mathrm{D}_{\mathrm{i}}^{*}$ and $\mathrm{T}$ are seen for $\mathrm{Li}, \mathrm{Sc}, \mathrm{V}, \mathrm{Sr}$ and $\mathrm{Ba}$, whereas a negative correlation exists for Zr. $\mathrm{D}_{\mathrm{i}}^{*}$ values for $\mathrm{Sc}, \mathrm{V}, \mathrm{Sr}, \mathrm{Cs}$ and Ba have a tendency toward equal partitioning as temperature increases (Fig. 7), as predicted from fundamental thermodynamic considerations. However, all of these trace element partitionings except for $\mathrm{V}$ are also controlled by major element compositions. Recall that V concentrations in biotite show the least major element compositional effects among the $3+$ cations in VI-sites (Fig. 5c).

Despite the occurrence of $\mathrm{Zr}^{4+}$ in biotite and muscovite at trace levels, the chemical potential of $\mathrm{Zr}$ is buffered by phase relations with zircon in the rocks. Thus, at equilibrium, partitioning of $\mathrm{Zr}$ may reveal changes in $\mathrm{P}-\mathrm{T}$. $\mathrm{Zr}$ is preferentially incorporated into muscovite over the temperature range of the studied samples $\left(450\right.$ to $650^{\circ} \mathrm{C}$ ), resulting in a four-fold decrease in the distribution coefficients (Fig. 7f). Major element compositions are not correlated with the distribution of $\mathrm{Zr}$ between biotite and muscovite.

The ratio of $\mathrm{D}_{C s}^{*} / \mathrm{D}_{R b}^{*}$ shows good correlation with metamorphic temperature (Fig. 7g). This may be explained by the relationship between the elasticity of interlayer sites and temperature, as shown in Figures 3 and 4. In this scenario, the distribution line for $1+$ cations in XII-sites would rotate clockwise around an axis at $\mathrm{K}^{+}$as the temperature increases, to approach equal partitioning, resulting in the decrease of $\mathrm{D}_{C s}^{*} /$ $\mathrm{D}_{R b}^{*}$ ratios. Elements whose ionic radii are close to the optimum ionic radii for specific sites in the micas do not show significant variation in distribution coefficients with temperature. In addition, as mentioned earlier, $\mathrm{D}_{i}^{*}$ ratios are also controlled by the phengite contents of muscovite which are correlated with pressure.

Among the trace elements showing thermal dependence, distributions of $\mathrm{V}$ and $\mathrm{Zr}$ show significant thermal effects with no major element compositional effects. However, for the distribution of $\mathrm{Li}, \mathrm{Sc}, \mathrm{Sr}$ and $\mathrm{Ba}$ between biotite and muscovite, it is difficult to separate thermal dependence from major element compositional and structural effects, because $\mathrm{X}_{\mathrm{Mg}}$ ratios of both biotite and muscovite are dependent on metamorphic temperature, which in turn affects the structure of interlayer sites of micas.

\section{CONCLUSIONS}

The systematic distribution of trace elements in coexisting biotite and muscovite indicates that equilibrium was achieved between these minerals in the analyzed metamorphic rocks. Distribution behaviour between biotite and muscovite for many elements is compatible with lattice strain theory, especially in interlayer sites of micas. Unfortunately, none of the trace elements investigated promises simply applicable alternative geothermometers for the metamorphic environment. The thermal dependences derived here for $\mathrm{Li}, \mathrm{Sc}, \mathrm{Sr}$ and $\mathrm{Ba}$ partitioning between biotite and muscovite are not strong enough, and it was not possible to separate them from major element compositional and structural effects. However, the trace element partitioning data for $\mathrm{V}$ and $\mathrm{Zr}$ may be used to cross-check con- ventional geothermometers for samples from a similar range of $\mathrm{P}-\mathrm{T}$ and bulk composition, especially when conventional geothermometers suffer from retrograde resetting and/or high $\mathrm{Fe}^{3+}$ contents. The ranges and dependences of distribution coefficients on major element compositions established here, for quartzofeldspathic and metapelitic rocks from upper greenschist to upper amphibolite facies, also provide important constraints on the values that can be used in modeling trace element zoning of garnet, because biotite and muscovite participate in many prograde metamorphic reactions.

Acknowledgments-We are grateful to Maggy Piranian and Mike Tubrett for help with the electron microprobe and LAM-ICP-MS analyses, respectively. This study was funded by NSERC grants to T. Rivers. We thank two anonymous journal reviewers for very perceptive critical comments.

\section{REFERENCES}

Bailey S. W. (1984) Crystal chemistry of the true micas. In Micas (ed. S. W. Bailey). Rev. Min. Vol. 13. Chap. 2, pp. 13-57.

Bea F., Cámara F., Soler J. M. F., Pugnaire M. T. G., Pereira M. D., and Stroh A. (1993) Trace element determination in minerals: Analyses of concentrates versus laser ablation techniques-Case study: Biotites from granitic rocks. Eur. Winter Conf. Plasma Spectrom. p. $\mathbf{4 0 .}$

Bea F., Montero P., Garut G., and Zacharini F. (1997) Pressuredependence of rare earth element distribution in amphibolite and granulite-grade garnets. A LA-ICP-MS study. Geostandards Newslett. 21, 253-270.

Beattie P. (1994) What determines the values of mineral/melt partition coefficients? Mineral. Mag. 58A, 63-64.

Beattie P., Drake M., Jones J., Leeman W., Longhi J., McKay G., Nielsen R., Palme H., Shaw D., Takahashi E., and Watson B. (1993) Terminology for trace-element partitioning. Geochim. Cosmochim. Acta 57, 1605-1606.

Berman R. G. (1991) Thermobarometry using multi-equilibrium calculations: A new technique, with petrological applications. Can. Mineral. 29, 833-855.

Blundy J. D. and Wood B. J. (1991) Crystal-chemical controls on the partitioning of $\mathrm{Sr}$ and $\mathrm{Ba}$ between plagioclase feldspar, silicate melts, and hydrothermal solutions. Geochim. Cosmochim. Acta 55, 193209.

Blundy J. and Wood B. (1994) Prediction of crystal-melt partition coefficients from elastic moduli. Nature 372, 452-454.

Brenan J. M., Shaw H. F., Ryerson F. J., and Phinney D. L. (1995) Mineral-aqueous fluid partitioning of trace elements at $900^{\circ} \mathrm{C}$ and $2.0 \mathrm{GPa}$ : Constraints on the trace element chemistry of mantle and deep crustal fluids. Geochim. Cosmochim. Acta 59, 3331-3350.

Brown D., Rivers T., and Calon T. (1992) A structural analysis of a metamorphic fold-thrust belt, northeast Gagnon terrane, Grenville province. Can. J. Earth Sci. 29, 1915-1927.

Butler B. C. M. (1967) Chemical study of minerals from the Moine schists of the Ardnamurchan area, Argyllshire, Scotland. J. Petrol. 8, 233-267.

Connelly J. N., van Gool J., Rivers T., and James D. T. (1996) Field guide to the geology of the Grenville Province of western Labrador. Pre-conference field excursion. Proterozoic Evolution in the North Atlantic Realm, COPENA-ECSOOT-IBTA Conference, Goose Bay, Labrador, July 29-August 2, 1996, Field excursion guide No. 1.

Dahl P. S., Wehn D. C., and Feldmann S. G. (1993) The systematics of trace-element partitioning between coexisting muscovite and biotite in metamorphic rocks from the Black Hills, South Dakota, USA. Geochim. Cosmochim. Acta 57, 2487-2505.

Domanik K. J., Hervig R. L., and Peacock S. M. (1993) Beryllium and boron in subduction zone minerals: An ion microprobe study. Geochim. Cosmochim. Acta 57, 4997-5010.

Dutrow B. L., Holdaway M. J., and Hinton R. W. (1986) Lithium in staurolite and its petrologic significance. Contrib. Mineral. Petrol. 94, 496-506. 
Govindaraju K. (1994) 1994 compilation of working values and sample description for 383 geostandards. Geostandards Newslett. 18, p. 158.

Guidotti C. V. and Sassi F. P. (1998a) Miscellaneous isomorphous substitutions in $\mathrm{Na}-\mathrm{K}$ white micas: A review, with special emphasis to metamorphic micas. Rend. Fis. Acc. Lincei. 9, 57-78.

Guidotti C. V. and Sassi F. P. (1998b) Petrogenetic significance of Na-K white mica mineralogy: Recent advances for metamorphic rocks. Eur. J. Min. 10, 815-854.

Haack U., Heinrichs H., Boneb, M., and Schneider A. (1984) Loss of metals from pelites during regional metamorphism. Contrib. Mineral. Petrol. 85, 116-132.

Harlow G. E. (1995) Crystal chemistry of barian enrichment in micas from metasomatized inclusions in serpentinite, Motagua Fault Zone, Guatemala. Eur. J. Mineral. 7, 775-789.

Heinrich W., Andrehs G., and Franz G. (1997) Monazite-xenotime miscibility gap thermometry; 1 . An empirical calibration. J. Metamorphic Geol. 15, 3-16.

Hervig R. L. and Peacock S. M. (1989) Water and trace elements in coexisting muscovite and biotite from metamorphic rocks. EOS 70, 490 (abstr.).

Hickmott D. D. and Spear F. S. (1992) Major and trace-element zoning in garnets from calcareous pelites in the NW Shelburne Falls quadrangle, Massachusetts: Garnet growth histories in retrograded rocks. J. Petrol. 33, 965-1005.

Hickmott D. D., Shimizu N., Spear F. S., and Selverstone J. (1987) Trace-element zoning in a metamorphic garnet. Geology 15, 573576.

Hodges K. V. and Crowley P. D. (1985) Error estimation and empirical geothermobarometry for pelitic systems. Amer. Mineral. 70, 702709 .

Hoinkes G. (1986) Effect of grossular-content in garnet on the partitioning of $\mathrm{Fe}$ and $\mathrm{Mg}$ between garnet and biotite. Contrib. Mineral. Petrol. 92, 393-399.

Holdaway, M. J., Mukhopadhyay B., Dyar M. D., Guidotti C. V., and Dutrow B. L. (1997) Garnet-biotite geothermometry revised; new Margules parameters and a natural specimen data set from Maine. Amer. Mineral. 82, 582-595.

Iiyama J. T. (1979) Trace element distribution in rock-forming silicates. The alkali and alkaline earths: Origin and distribution of the elements. Physics Chem. Earth II, 161-174.

Jackson S. E., Longerich H. P. Dunning G. R., and Fryer B. J. (1992) The application of laser-ablation microprobe-inductively coupled plasma-mass spectrometry (LAM-ICP-MS) to in situ trace-element determinations in minerals. Can. Mineral. 30, 1049-1064.

Jenner G. A., Foley S. F., Jackson S. E., Green T. H., Fryer B. J., and Longerich H. P. (1994) Determination of partition coefficients for trace elements in high pressure-temperature experimental run products by laser ablation microprobe-inductively coupled plasma-mass spectrometry (LAM-ICP-MS). Geochim. Cosmochim. Acta 58, 5099-5103.

Jensen B. B. (1973) Patterns of trace element partitioning. Geochim. Cosmochim. Acta 37, 2227-2242.

Johnson C. A. (1994) Partitioning of zinc among common ferromagnesian minerals and implications for hydrothermal mobilization. Can. Mineral. 32, 121-132.

Kretz R. (1961) Some applications of thermodynamics to coexisting minerals of variable composition. Examples: orthopyroxene-clinopyroxene and orthopyroxene-garnet. J. Geol. 69, 361-387.

Kretz R. (1983) Symbols for rock-forming minerals. Am. Mineral. 68, 277-279.

Kretz R., Campbell J. L., Hoffman E. L., Hartree R., and Teesdale W. J. (1999) Approaches to equilibrium in the distribution of trace elements among the principal minerals in a high-grade metamorphic terrane. J. Metamorphic Geol. 17, 41-59.

LaTourrette T, Hervig R. L., and Holloway J. R. (1995) Trace element partitioning between amphibole, phlogopite, and basanite melt. Earth. Planet. Sci. Lett. 135, 13-30.
Longerich H. P., Jackson S. E., and Günther D. (1996) Laser ablation inductively coupled plasma mass spectrometric transient signal data acquisition and analyte concentration calculation. J. An. At. Spectr. 11, 899-904.

Matsui Y., Onuma N., Nagasawa H., Higuchi H., and Banno S. (1977) Crystal structure control in trace element partition between crystal and magma. Bull. Soc. Fr. Mineral. Cristallogr. 100, 315-324.

Michael P. (1988) Partition coefficients for rare earth elements in mafic minerals of high silica rhyolites: The importance of accessory mineral inclusions. Geochim. Cosmochim. Acta 52, 275-282.

Möller P. (1988) The dependence of partition coefficients on differences of ionic volumes in crystal-melt systems. Contrib. Mineral. Petrol. 99, 62-69.

Moorbath S., Bell K., Leake B. E., and McKerrow W. S. (1968) Geochronological studies in Connemara and Murrisk, Western Ireland. In Radiometric Dating for Geologists (eds. E. I. Hamilton and R. M. Farquhar). pp. 259-298. Interscience.

Onuma N., Higuchi H., Wakita H., and Nagasawa H. (1968) Trace element partition between two pyroxenes and the host lava. Earth Planet. Sci. Lett. 5, 47-51.

Rivers T. (1983a) The northern margin of the Grenville Province in western Labrador-Anatomy of an ancient orogenic front. Precamb. Res. 22, 41-73.

Rivers T. (1983b) Progressive metamorphism of pelitic and quartzofeldspathic rocks in the Grenville Province of western Labradortectonic implications of bathozone 6 assemblages. Can J. Earth. Sci. 20, 1791-1804.

Rivers T., van Gool J. A. M., and Connelly J. N. (1993) Contrasting tectonic styles in the northern Grenville province: Implications for the dynamics of orogenic fronts. Geology 21, 1127-1130.

Schwarz S. H. (1998) Structural, metamorphic and tectonic studies in central Gagnon terrane, Grenville Province. M. Sc. Thesis, Memorial University of Newfoundland.

Shannon R. D. (1976) Revised effective ionic radii and systematic studies of interatomic distances in halides and chalcogenides. Acta. Cyst. A32, 751-767.

Shearer C. K., Papike J. J., Simon S. B., and Laul J. C. (1986) Pegmatite-wallrock interaction, Black Hills, South Dakota: Interaction between pegmatite-derived fluids and quartz-micas schist wallrock. Am. Mineral. 71, 518-539.

Taylor R. P., Jackson S. E., Longerich H. P., and Webster J. D. (1997) In situ trace-element analysis of individual silicate melt inclusions by laser ablation microprobe-inductively coupled plasma-mass spectrometry (LAM-ICP-MS). Geochim. Cosmochim. Acta 61, 25592567.

van Gool J. A. M. (1992) The thermotectonic development of the Grenville front fold-and-thrust belt in southwestern Labrador. Ph. D. thesis, Memorial University of Newfoundland.

Volfinger M. (1974) Effet de la composition des micas trioctaëdriques sur les distributions de Rb et Cs à l'état de traces. Earth Planet. Sci. Lett. 24, 299-304.

Volfinger M. (1976) Effet de la température sur les distributions de $\mathrm{Na}$, $\mathrm{Rb}$ et $\mathrm{Cs}$ entre la sanidine, la muscovite, la phlogopite et une solution hydrothermale sous une pression de 1 kbar. Geochim. Cosmochim. Acta 40, 267-282.

Volfinger M. and Robert J. L. (1980) Structural control of the distribution of trace elements between silicates and hydrothermal solutions. Geochim. Cosmochim. Acta 44, 1455-1461.

Williams M. L. and Grambling J. A. (1990) Manganese, ferric iron and the equilibrium between garnet and biotite. Am. Mineral. 75, 886908.

Yang P., Rivers T., and Jackson S. (1999) Crystal-chemical and thermal controls on trace-element partitioning between coexisting garnet and biotite in metamorphic rocks from western Labrador. Can. Mineral. 37, 443-468.

Zen E-an (1963) Components, phases and criteria of chemical equilibrium in rocks. Am. J. Sci. 261, 929-942. 